\title{
Preparation and Characterization of Nano Structured Pt-MOx/C for Oxygen Reduction Reaction in Acidic Medium
}

\author{
K.M. El-Khatib ${ }^{1 *}$, Amani E. Fetohi ${ }^{1}$, R.S. Amin ${ }^{1}$ and R.M. Abdel Hameed ${ }^{2}$ \\ ${ }^{1}$ Chemical Engineering Department, National Research Center,El-Buhous st.,Dokki \\ and ${ }^{2}$ Chemistry Department, Faculty of Science, Cairo University, Giza, Egypt.
}

\begin{abstract}
$\mathbf{P}$ t-MOx/C (M = Ti, Ce or $\mathrm{Zr}$ ) electrocatalysts was prepared for the purpose of developing a cheap and efficient electrocatalysts for oxygen reduction reaction (ORR) using a mixture of ethylene glycol and sodium borohydride $\left(\mathrm{EG}+\mathrm{NaBH}_{4}\right)$ as areducing agent. $\mathrm{Pt} / \mathrm{C}$ was studied for estimation of metal oxides effect.Pt- $\mathrm{CeO}_{2} / \mathrm{C}-1$ was prepared through single reducing agent ethylene glycol for studying the effect of changing the reducing agent on the activity of electrocatalysts toward ORR and for studying ORR kinetics. The electrocatalytic activity of the prepared electrocatalysts towards (ORR) was evaluated by cyclic voltammetry (CV) and linear sweep voltammetry (LSV) on a rotating disc electrode (RDE). $\mathrm{Pt}_{-\mathrm{ZrO}} / \mathrm{C}$ shows the best activity towards ORR among the studied electrocatalysts; the oxygen reduction current density for it is about 5 times; $\left(5.84 \mathrm{mAcm}^{-2}\right)$ as that of $\mathrm{Pt} / \mathrm{C}\left(1.26 \mathrm{mAcm}^{-2}\right) . \mathrm{Pt}-\mathrm{CeO}_{2} / \mathrm{C}$ showed better ORR activity $\left(2.24 \mathrm{mAcm}^{-2}\right)$ than $\mathrm{Pt}_{-} \mathrm{CeO}_{2} / \mathrm{C}-1\left(1.58 \mathrm{mAcm}^{-2}\right)$ indicating the great effect of changing the reducing agent not only on the electrocatalyst behavior towards ORR but also its particle size and the metal content of the resultant electrocatalysts. Oxygen reduction mechanism for Pt- $\mathrm{CeO}_{2} / \mathrm{C}$ and $\mathrm{Pt}-\mathrm{CeO}_{2} / \mathrm{C}-1$ was evaluated using through KouteckyLevich, they showed first-order kinetics with ORR not controlled solely by diffusion. $\mathrm{XRD}$, EDX and TEM analyses were used to characterize the prepared electrocatalyst.
\end{abstract}

Keywords: Oxygen reduction reaction, platinum nanoparticles, metal oxides, rotating disk electrode.

\section{Introduction}

Oxygen reduction reaction (ORR) is one of the most important electrocatalytic reactions because of its role in corrosion of metals and electrochemical energy conversion especially in the field of fuel cells applications[1]. The cell voltage values of fuel cells are limited due to the slowness of ORR at the cathode. The most used electrocatalyst for ORR is platinum which is highly active chemically stable, but $\mathrm{Pt}$ is expensive and limited in the world's supply; this results in difficulty of widespread commercialization of the fuel cell technology. So, research efforts in the development of cathode electrocatalysts have been focused on reducing the Pt content or replacing it with less expensive materials with maintaining high ORR activity[2], so getting electrocatalysts in which transition metals have been alloyed with noble metals is a need[3-5].

The principal problems that inhibit direct methanol fuel cells (DMFCs) commercialization are: development of a highly active and CO- tolerant anode catalysts and the overcoming of the oxygen reduction reaction (ORR) slowness at the cathode [6].Considering that Pt catalysts alone we face a problem of the slowness of ORR which is due to the formation of $-\mathrm{OH}$ species at $+0.8 \mathrm{~V}$ that inhibits further reduction of oxygen and hence results in loss of performance[7] .So, composite Pt-based electrocatalysts containing rare earth oxides have shown a number of characteristics that make them promising for catalytic studies due to the harmonic electronic effect in combining metal oxides, carbon and Pt. Strong d-d-Metal-Support Interaction of hyper-d-electronic metal with mostly hypo-doxide $\left(\mathrm{TiO}_{2}, \mathrm{ZrO}_{2}, \mathrm{HfO}_{2}\right)$ implies that the d-dmetal-oxide interaction is in accordance with the bonding strength which results in weakening of intermediate chemisorptive bonds (M-H, M-CO) [8-12].Among the studied metal oxides, $\mathrm{CeO}_{2}$ is predominant in the applications as catalyst support[13-17]. $\mathrm{CeO}_{2}$ is a fluorite oxide whose cations can switch between +3 and +4 oxidation states, here the oxide acts as an oxygen buffer 
to control oxygen concentration at the catalyst surface. This may be due to the enhancement of the interaction between Pt and ceria for the catalytic activities of Pt $[18,19]$. Cerium oxide nanoparticles were in-situ grown on reduced graphene oxide (rGO) through thermal treatment of the $\mathrm{Ce}^{3+}$-doped graphene oxide(GO) under nitrogen atmosphere. The nano composites show electrocatalytic activity toward the oxygen reduction reaction (ORR) in alkaline solution. Especially, the cerium oxide nanoparticles/rGO nanocomposites treated at 750 $\mathrm{C}$ possess excellent electrocatalytic ability with a dominating four-electron pathway[20].

$\mathrm{TiO}_{2}$ is promising because of its good electrochemical properties, chemical stability and non-toxic nature[21]. $\mathrm{Pt}-\mathrm{TiO}_{2} / \mathrm{C}$ shows improved stability in polymer electrolyte membrane fuel cells (PEMFCs) compared with Pt/C[22].In spite of the amount of titanium dioxide and the crystalline phase $\left(\mathrm{TiO}_{2}\right.$ anatase/rutile phase) it was found that, it modifies the strength of the interaction between the substrate and the metal nanoparticles[23, 24]. The good effect of addition $\mathrm{TiO}_{2}$ may be attributed to two factors which are: the changes in the Pt-d electronic properties and the geometric effect that leads to the Pt-Pt bonding distance contraction and hence results in a sensible improvement of the electrochemical reactions $[25,26]$. Titanium oxidebased cathode, synthesized from oxy-titanium tetra-pyrazinoporphyrazine by the oxidation under a low partial pressure of oxygen using carbon nanotubes as a support, showed high reactivity in the four-electron reduction of oxygen[27]. Platinum nanoparticles (Pt NPs) have been anchored by photo deposition on titanium oxide $\left(\mathrm{TiO}_{2}\right)$ matrix which is formed via titanium isopropoxide hydrolysis on cup-stacked carbon nanotubes (CSCNT) in isopropanol, the resultant composite Pt catalyst was tested for oxygen reduction reaction (ORR) in acidic media and the results revealed that the anchoring of Pt NPs on the $\mathrm{TiO}_{2}$ support material deposited on CSCNT is an effective way to enhance the ORR activity of Pt NPs[28]. A 15 wt.\% Pt-based catalyst was developed on a mixture of titanium suboxides, with an excess of the Ti3O5 phase, doped with $\mathrm{Mo}$, as a $\mathrm{Ti}_{3} \mathrm{O}_{5}$-Mo without carbon support and compared to a commercial 20 wt.\% Pt/C (E-TEK). The $\mathrm{Pt} / \mathrm{Ti}_{3} \mathrm{O}_{5}$-Mo catalyst shows an excellent electroactivity and stability toward the ORR, reaching a performance of 73.3 $\mathrm{mA} \mathrm{mg}{ }^{-1}$, nearly twice as that of the commercial $\mathrm{Pt} / \mathrm{C}$, with a current density of $1.1 \mathrm{~mA} \mathrm{~cm}^{-2}$ at 0.9 $\mathrm{V}$ vs RHE, and an half-wave potential of $0.86 \mathrm{~V}$ vs RHE [29]. Pt/ZrO $@$ @Nx has been synthesized by forming a highly conductive nitrogen-doped carbon layer on the surface of $\mathrm{ZrO}_{2}\left(\mathrm{ZrO}_{2} @ \mathrm{CNx}\right)$ the final step is the Pt nanoparticles deposition. The Pt/ZrO $@$ @Nx catalyst showed a high electrocatalytic activity for the oxygen reduction reaction (ORR)[30]. A two-step method has been used by G. Liu et al. to prepare $\mathrm{Pt}_{4} \mathrm{ZrO}_{2} / \mathrm{C}$ catalyst as a cathode catalyst in a high temperature PEMFC based on $\mathrm{H}_{3} \mathrm{PO}_{4}$ doped polybenzimidazole (PBI) to investigate the cell performance[31]. Cobalt oxide $\left(\mathrm{Co}_{3} \mathrm{O}_{4}\right)$ nanocubes were incorporated into reduced graphene oxide (RGO) using a simple singlestep hydrothermal reaction for an electrocatalytic oxygen reduction reaction (ORR). The RGO@ $\mathrm{Co}_{3} \mathrm{O}_{4}$ nano hybrid with $4 \mathrm{wt} \%$ of graphene oxide modified glassy carbon (GC) electrode exhibited better electrocatalytic activity when compared to the other controlled modified electrodes and commercial $\mathrm{Pt} / \mathrm{C}$ catalyst for the ORR in an alkaline medium[32]. Bifunctional electrocatalysts series composed of nitrogen-doped grapheme cobalt oxide nanoparticles nano-hybrids (Co$\mathrm{N} / \mathrm{G}$ ) are fabricated through one-pot hydrothermal synthesis, The optimized Co-N/G catalyst consists of the highest contents of pyridinic nitrogen and $\mathrm{CoO}$, efficiently catalyze both ORR and OER[33].

Microwave-assisted technology has been widely used for preparing many nanomaterials because it is a quick, simple, homogeneous and efficient method [34-36]. Smaller particles were formed when microwave irradiation method was adopted. It was reported that Pt particles with about 3-4 $\mathrm{nm}$ size exhibited a higher mass electrocatalytic activity for oxygen reduction [37, 38]. Pt-Ru particles with $3 \mathrm{~nm}$ size displayed the highest mass catalytic activity for methanol electrooxidation [39]. So as a direct result, microwave irradiation method is applicable in different areas namely; materials synthesis, food drying, microwave-induced catalysis and plasma chemistry [40-43].

The present work aims to study physical and electrochemical behavior of $\mathrm{Pt}-\mathrm{MOx} / \mathrm{C}$ electrocatalysts, where $\mathrm{MOx}$ refers to $\mathrm{TiO} 2, \mathrm{CeO} 2$ and $\mathrm{ZrO}_{2}$ in order to develop a cheaper and more efficient electrocatalyst for oxygen reduction reaction. $\mathrm{Pt} / \mathrm{C}$ has been studied to evaluate the metal oxide effect; $\mathrm{Pt}-\mathrm{CeO}_{2} / \mathrm{C}-1$ has been studied to evaluate the effect of the changing of the used reducing agent on the behavior of the prepared electrocatalyst. 


\section{Experimental}

Catalyst synthesis

All the reagents in this synthesis were in analytical grade (Sigma-Aldrich) and used without further purification. Double distilled water was used in all aqueous solutions preparation and washing. According to this preparation method, we have synthesized $\mathrm{Pt}-\mathrm{TiO}_{2} / \mathrm{C}, \mathrm{Pt}-\mathrm{CeO}_{2} / \mathrm{C}$ and $\mathrm{Pt}-$ $\mathrm{ZrO}_{2} / \mathrm{C}$ electrocatalysts using titanium (IV) oxide $\left(\mathrm{TiO}_{2}\right)$, cerium (IV) oxide $\left(\mathrm{CeO}_{2}\right)$ and zirconium (IV) oxide $\left(\mathrm{ZrO}_{2}\right)$, respectively through two steps. The first step involved the synthesis of $\mathrm{MO}_{\mathrm{x}} / \mathrm{C}$ powders via solid state reaction under intermittent microwave heating, while the second step is platinum loading on $\mathrm{MO}_{\mathrm{x}} / \mathrm{C}$ surfaces. To prepare $\mathrm{MO}_{\mathrm{x}} / \mathrm{C}$, a fixed amount of titanium (IV) oxide $\left(\mathrm{TiO}_{2}\right)$, cerium (IV) oxide $\left(\mathrm{CeO}_{2}\right)$ or zirconium (IV) oxide $\left(\mathrm{ZrO}_{2}\right)$ [5 wt.\%] well dispersed over carbon black Vulcan $\mathrm{XC}-72 \mathrm{R}$ using a mixture of second distilled water and isopropanol in the ratio of (1:1). This suspension was stirred using magnetic stirrer for $30 \mathrm{~min}$ and heated into a microwave oven (Caira CA-MW1025, touch pad digital control, $50 \mathrm{MHz}, 1400 \mathrm{~W}$ ) in six cycles; each cycle was $20 \mathrm{~s}$ on and $60 \mathrm{~s}$ off. The next step is the filtration of the mixture and washing it with double distilled water for 6 times, the last step is drying in an air oven at $80^{\circ} \mathrm{C}$ for $6 \mathrm{~h}$. Reduction of platinum on the prepared $\mathrm{MO}_{\mathrm{x}} / \mathrm{C}$ powders is done through modified microwaveassisted polyol process in which $\mathrm{H}_{2} \mathrm{PtCl}_{6}$ solution was added to a suspension of $\mathrm{MO}_{\mathrm{x}} / \mathrm{C}$ powder in distilled water with adjusting $\mathrm{Pt}$ loading at 25 wt.\%. For this step, a mixture of ethylene glycol and sodiumborohydride $\left(\mathrm{EG}+\mathrm{NaBH}_{4}\right)$ were used (in this case the electrocatalysts are assigned as $\mathrm{Pt}-\mathrm{MO} / \mathrm{C}) . \mathrm{pH}$ of the solution was adjusted at 10 using $0.4 \mathrm{M} \mathrm{KOH}$ in ethylene glycol to induce the formation of small and uniform Pt nanoparticles. This mixture was then heated into the microwave oven for $50 \mathrm{~s}$ in one continuous mode. $\mathrm{Pt}-\mathrm{MO}_{\mathrm{x}} / \mathrm{C}$ powder was then filtered, washed and dried. Pt$\mathrm{CeO}_{2} / \mathrm{C}$-1was prepared via the same procedure using single reducing agent ethylene glycol (EG) for studying the effect of changing the reducing agent during the preparation process.

\section{Physical characterization}

XRD, TEM and EDX analyses are used to describe $\mathrm{Pt} / \mathrm{C}$ and the mentioned $\mathrm{Pt}-\mathrm{MOx} / \mathrm{C}$ electrocatalysts physically. Specifications of devices used to evaluate these types of analyses are: a RigakuD/MAX-PC 2500 X-ray diffractometer equipped with $\mathrm{Ni}$ filtered $\mathrm{Cu} \mathrm{Ka}$ as the radiation source. The tube current was $40 \mathrm{~mA}$ with a voltage of $40 \mathrm{kV}$ to evaluate the crystalline structure of the prepared electrocatalysts. TEM and EDX analyses was performed using JEOL-JEM 2010 transmission electron microscope that operated at an accelerating voltage of $160 \mathrm{kV}$

\section{Electrochemical measurements}

Voltamaster 6 potentiostat and Rotating Disc Electrode (RDE) were employed for the electrochemical measurements. It is connected to a personal computer as data interface. Cyclic voltammetry $(\mathrm{CV})$ and linear sweep voltammetry (LSV) were conducted to measure the electrocatalytic activity of the prepared $\mathrm{Pt}-\mathrm{MO}_{\mathrm{x}} / \mathrm{C}$ electrocatalysts towards oxygen reduction reaction. The three electrode cell consists of $\mathrm{Pt}$ wire and $\mathrm{Ag} /$ $\mathrm{AgCl}$ as the counter and the reference electrodes, respectively. All the potential values in this work are referred to RHE. The working electrode was a thin film of electrocatalyst supported on glassy carbon (GC) electrode (with geometrical surface area of $0.196 \mathrm{~cm}^{2}$ ) which is a part of the RDE. This GC electrode was first polished using 0.05 $\mu \mathrm{m}$ alumina powder and soft cloth then carbonsupported electrocatalyst was put on it mixed with 1 droplet of isopropanol, two consecutive droplets of $5 \%$ Nafion solution were put after isopropanol has dried, at last a second droplet of isopropanol was added, the electrocatalyst thin film was left till air drying. The catalyst loading is $0.6 \mathrm{mg} / \mathrm{cm}^{2}$.

For the electrochemical active surface area (ECSA) determination experiments, they were carried out at room temperature employing $0.5 \mathrm{M}$ $\mathrm{H}_{2} \mathrm{SO}_{4}$ as the electrolyte solution and three electrode system in which $\mathrm{Hg} / \mathrm{Hg}_{2} \mathrm{SO}_{4} / 1.0 \mathrm{M} \mathrm{H}_{2} \mathrm{SO}_{4}(\mathrm{MMS})$ is the reference electrode. Thirty CVs with scan rate of $50 \mathrm{mVs}^{-1}$ at a potential window (-700 to 900 $\mathrm{mV} / \mathrm{MMS}$ ) (-80 to $1520 \mathrm{mV} / \mathrm{RHE}$ ) was conducted.

All electrochemical experiments were carried out at room temperature and ambient pressure employing $0.5 \mathrm{M} \mathrm{H}_{2} \mathrm{SO}_{4}$ as the electrolyte solution. At first nitrogen was bubbled for $20 \mathrm{~min}$. The CV scan at the 10th cycle is recorded scan rate of $50 \mathrm{mVs}-1$ with a potential window $(-200$ to $1000 \mathrm{mV} / \mathrm{Ag} / \mathrm{AgCl})(-1$ to $1199 \mathrm{mV} / \mathrm{RHE})$ and one LSV with scan rate of $10 \mathrm{mVs}-1$ in a potential range (1000 to-200 $\mathrm{mV} / \mathrm{Ag} / \mathrm{AgCl}$ ) (1199 to-1 $\mathrm{mV} / \mathrm{RHE}$ ) was performed, then oxygen bubbling for $30 \mathrm{~min}$, after that LSVs with different rpm values ranging between $200 \mathrm{rpm}$ to $2400 \mathrm{rpm}$ were performed in solution saturated with 
oxygen with the same conditions as in case of LSV performed in solution saturated with nitrogen. The same conditions of $\mathrm{CV}$ recorded in nitrogen is repeated in case of oxygen.

\section{$\underline{\text { Results and Discussion }}$}

Physical characterization of $\mathrm{Pt}-\mathrm{MOx} / \mathrm{C}$ electrocatalysts

Figure (1a) showed the X-ray diffraction (XRD) of $\mathrm{Pt}-\mathrm{TiO}_{2} / \mathrm{C}, \mathrm{Pt}-\mathrm{CeO}_{2} / \mathrm{C}$ and $\mathrm{Pt}-\mathrm{ZrO}_{2} / \mathrm{C}$ electrocatalysts in comparison with that of $\mathrm{Pt} / \mathrm{C}$. The diffraction peaks of $\operatorname{Pt}(111), \operatorname{Pt}(200)$ and $\mathrm{Pt}(220)$ appear in allelectrocatalysts. XRD pattern of $\mathrm{Pt}-\mathrm{CeO}_{2} / \mathrm{C}-1$ electrocatalysts shows that $\mathrm{CeO}_{2}$ has four diffraction peaks of $\mathrm{CeO}_{2}$ at $2 \theta=28.6^{\circ}, 33.1^{\circ}, 47.5^{\circ}$ and $56.3^{\circ}$ that correspond to (111), (200), (220) and (311) diffraction planes, respectively[44]. These are typical of single-phase oxides with fluorite structures. so, both $\mathrm{Pt}$ and $\mathrm{CeO}_{2}$ phases exist simultaneously in $\mathrm{Pt}-\mathrm{CeO}_{2} / \mathrm{C}$ electrocatalyst, it was also noticed that; after introducing $\mathrm{CeO}_{2}$ to $\mathrm{Pt} / \mathrm{C}$ in $\mathrm{Pt}-\mathrm{CeO}_{2} / \mathrm{C}$ electrocatalyst, $2 \theta$ values are shifted in the positive direction when compared to those of $\mathrm{Pt}$ in $\mathrm{Pt} / \mathrm{C}$ as shown in Table 1 while for $\mathrm{Pt}-\mathrm{ZrO} / \mathrm{C}$ electrocatalyst $\mathrm{Pt}(111)$, $\operatorname{Pt}(200)$ and $\operatorname{Pt}(220)$ planes are observed at $2 \theta$ $=39.765^{\circ}, 45.909^{\circ}$ and 67.6820 , respectively.

$\operatorname{Pt}(111)$ and $\operatorname{Pt}(220)$ planes are shifted to higher $2 \theta$ values when compared to those of $\mathrm{Pt} / \mathrm{C}$ as shown in Table 1 . This is an indication for the fact that incorporation of $\mathrm{ZrO}_{2}$ affects the crystalline lattice of platinum; no diffraction planes related to $\mathrm{ZrO}_{2}$ phase were found. This can be due to the low concentration of $\mathrm{ZrO}_{2}$ or partial $\mathrm{ZrO}_{2}$ entering into $\mathrm{Pt}$ crystalline lattice[45-48]. For $\mathrm{Pt}-\mathrm{TiO}_{2} / \mathrm{C}$ electrocatalyst we can notice that; $\operatorname{Pt}(111)$ Pt (200) and $\operatorname{Pt}(220)$ diffraction planes are found to be at higher $2 \theta$ values when compared to those in $\mathrm{Pt} / \mathrm{C}^{-1}$ as in Table 1 resulting in a crystal lattice contraction, it is also noticed from Fig.1 (a) that; no characteristic peak for $\mathrm{TiO}_{2}$ is found in XRD pattern, this could be interpreted by the existence of the titanium oxide in an amorphous form[49]. Pt (200) diffraction planes of $\mathrm{Pt}-\mathrm{CeO}_{2} / \mathrm{C}-1$, showed $2 \theta$ shift to higher values 47.326 when compared to that of $\mathrm{Pt}-\mathrm{CeO}_{2} / \mathrm{C} 47.319$ as seen from Fig. $1 \mathrm{~b}$ while the corresponding interplanar spacing parameter is constant 1.919. Pt (111) and $\mathrm{Pt}$ (220) diffraction planes of $\mathrm{Pt}-\mathrm{CeO}_{2} / \mathrm{C}-1$ show no values, so we can conclude that introducing $\mathrm{CeO}_{2}$ in $\mathrm{Pt}$ -

(a)

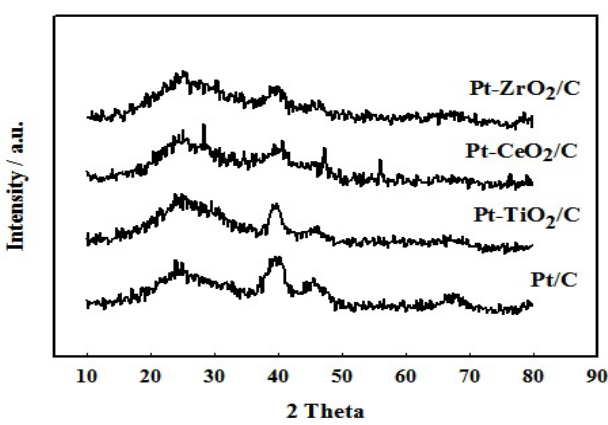

(b)

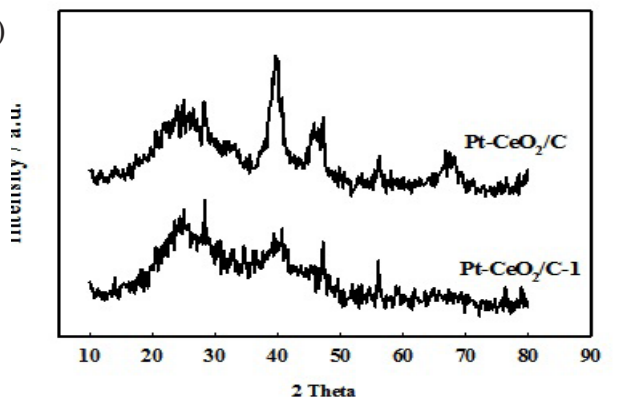

Fig.1. XRD patterns of (a) $\mathrm{Pt} / \mathrm{C}$ and different $\mathrm{Pt}-$ $\mathrm{MOx} / \mathrm{C}$, (b) $\mathrm{Pt}-\mathrm{CeO}_{2} / \mathrm{C}$ and $\mathrm{Pt}-\mathrm{CeO}_{2} / \mathrm{C}-1$ electrocatalysts.

TABLE 1. Variation of $2 \theta$ and d values of $\mathrm{Pt}(111)$, $\mathrm{Pt}(200)$ and $\mathrm{Pt}(220)$ diffraction peaks of $\mathrm{Pt} / \mathrm{C}$ and different $\mathrm{Pt}-$ MOx/C electrocatalysts.

\begin{tabular}{|l|c|c|c|c|c|c|c|}
\hline \multirow{2}{*}{ Electrocatalyst } & \multicolumn{2}{|c|}{$\mathbf{P t}(111)$} & \multicolumn{2}{c|}{$\operatorname{Pt(200)}$} & \multicolumn{2}{c|}{$\operatorname{Pt(220)}$} & \multirow{2}{*}{$\begin{array}{c}\text { Pt crystallite } \\
\text { size / nm }\end{array}$} \\
\cline { 2 - 7 } & $\mathbf{2 \theta} / \AA$ & $\mathbf{d} / \AA$ & $\mathbf{2 \theta} / \AA$ & $\mathbf{d} / \AA$ & $\mathbf{2 \theta} / \AA$ & $\mathbf{d} / \AA$ & \\
\hline $\mathrm{Pt} / \mathrm{C}$ & 39.265 & 2.293 & 46.001 & 1.971 & 67.353 & 1.389 & - \\
\hline $\mathrm{Pt}-\mathrm{TiO}_{2} / \mathrm{C}$ & 39.678 & 2.270 & 46.339 & 1.958 & 67.539 & 1.386 & - \\
\hline $\mathrm{Pt}-\mathrm{CeO}_{2} / \mathrm{C}$ & 39.621 & 2.272 & 47.319 & 1.919 & 67.563 & 1.385 & 3.2 \\
\hline $\mathrm{Pt}-\mathrm{ZrO}_{2} / \mathrm{C}$ & 39.765 & 2.264 & 45.909 & 1.975 & 67.682 & 1.383 & - \\
\hline $\mathrm{Pt}-\mathrm{CeO}_{2} / \mathrm{C}-1$ & - & - & 47.326 & 1.919 & - & - & - \\
\hline
\end{tabular}


$\mathrm{CeO}_{2} / \mathrm{C}-1$ leads to crystal lattice contraction. It was found that the $\mathrm{Pt}$ particle size for $\mathrm{Pt}$ in $\mathrm{Pt}-\mathrm{CeO} 2 / \mathrm{C}$ is $3.2 \mathrm{~nm}$ while that inPt-ZrO$/ \mathrm{C}$, Pt$\mathrm{TiO}_{2} / \mathrm{C}$ and $\mathrm{Pt}-\mathrm{CeO}_{2} / \mathrm{C}-1$ electrocatalysts could not be estimated, this phenomena is attributed to the fact that, XRD gives information about crystalline size information rather than true particle size[50].

Energy dispersive X-ray (EDX) analysis has been carried out to determine the elemental composition of the prepared $\mathrm{Pt} / \mathrm{C}$ and $\mathrm{Pt}-\mathrm{MO}_{\mathrm{x}} / \mathrm{C}$ electrocatalysts. Figure 2 (ae) present the (EDX) spectra of $\mathrm{Pt} / \mathrm{C}$, Pt$\mathrm{TiO}_{2} / \mathrm{C}$ and $\mathrm{Pt}-\mathrm{CeO}_{2} / \mathrm{C}, \mathrm{Pt}-\mathrm{ZrO}_{2} / \mathrm{C}$ and Pt$\mathrm{CeO}_{2} / \mathrm{C}$-1 electrocatalysts respectively. The weight and atomic percentages of different elements constituting these electrocatalysts are presented in Table 2. Wt. \% of $\mathrm{Pt}$ was found to be 36.03 in $\mathrm{Pt} / \mathrm{C}$ electrocatalyst. This percentage was increased when different MOx were introduced. All studied samples found to contain carbon, oxygen and platinum in different weight percentages. It is noticed from Table 2 that $\mathrm{Pt}-\mathrm{ZrO}_{2} / \mathrm{C}$ electrocatalyst showed the highest weight percentages of Pt (56.03) while $\mathrm{Pt}-\mathrm{CeO}_{2} / \mathrm{C}-1$ electrocatalyst showed the lowest one (10.39). On the other hand we found that; $\mathrm{Pt}-\mathrm{CeO}_{2} / \mathrm{C}$ has the highest weight percentage value for the metal (here; Ce) 8.84 . On studying the effect of reducing agent we can observe that, using single reducing agent (EG) decreases the Wt.\% of $\mathrm{Pt}$ and $\mathrm{M}$ (Ce) while increases that of $\mathrm{C}$ and $\mathrm{O}$. It was also noticed that the weight percentage of oxygen for electrocatalysts prepared using mixed reducing agent is low when compared to that prepared using single reducing agent.

Transmission electron microscopy (TEM) image of $\mathrm{Pt} / \mathrm{C}$ electrocatalyst was shown in Fig.

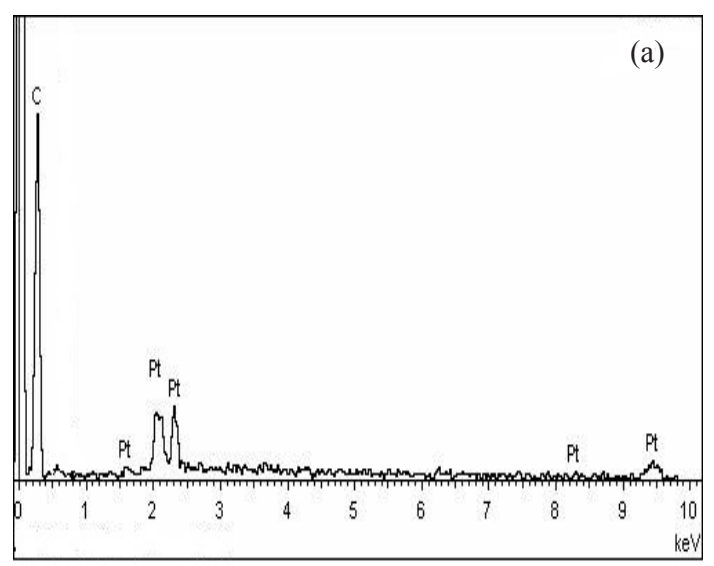

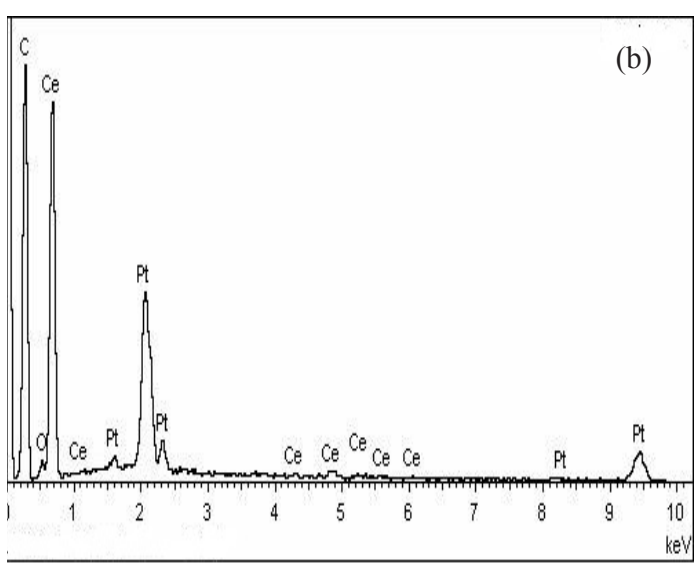
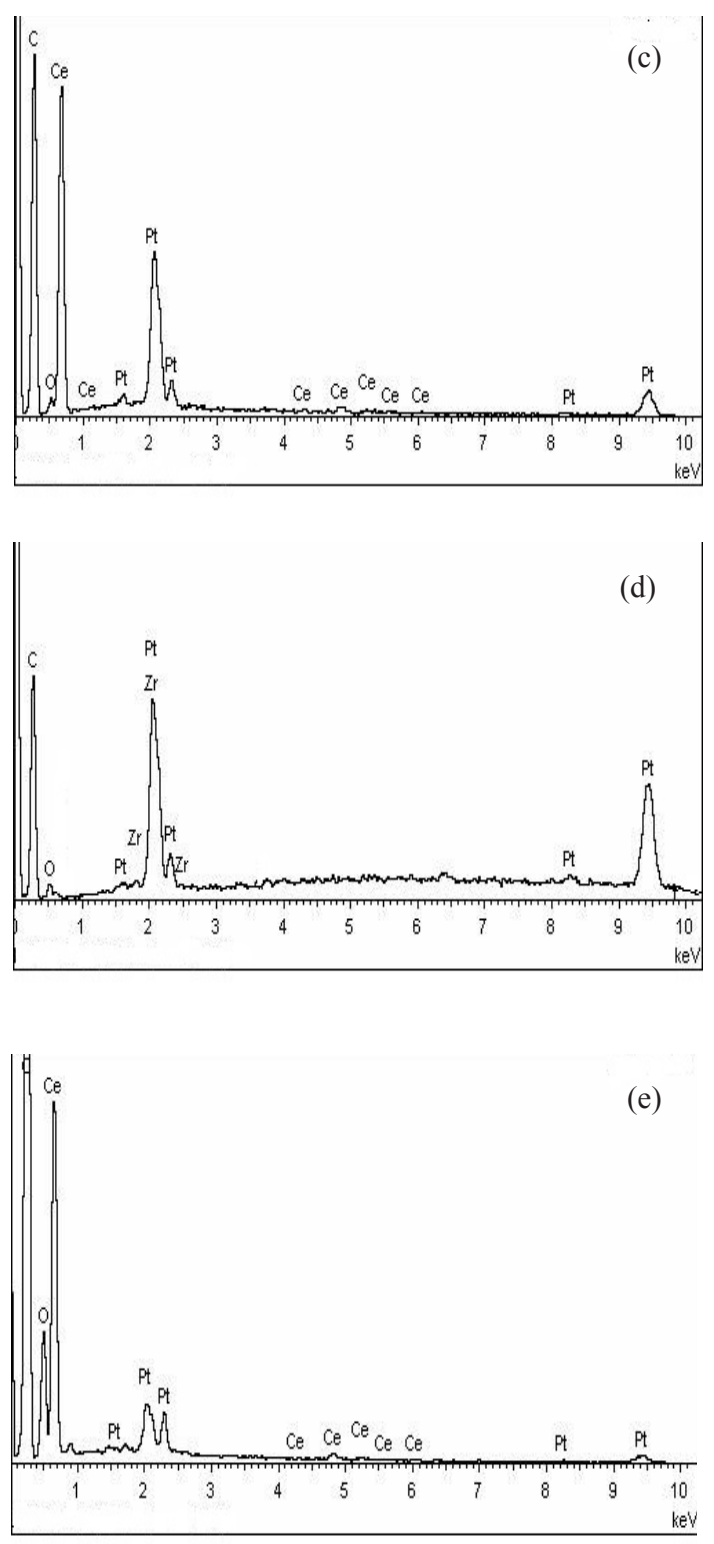

Fig. 2. EDX spectra of (a)Pt/C, (b)Pt-TiO2/C, (c) $\mathrm{Pt}-\mathrm{CeO} 2 / \mathrm{C}$, (d) $\mathrm{Pt}-\mathrm{ZrO} / \mathrm{C}$ and (e) $\mathrm{Pt}-$ $\mathrm{CeO} 2 / \mathrm{C}-1$ electrocatalysts.

Egypt. J. Chem. 60, No.3 (2017) 
$3 \mathrm{a}, \mathrm{a}^{\prime}$. A higher degree of particle agglomeration is observed with particle size of $3.57 \mathrm{~nm}$ as shown in Table 3. Figure (3b\& 3b') display TEM images of $\mathrm{Pt}-\mathrm{TiO}_{2} / \mathrm{C}$ electrocatalyst. The catalyst particles were homogeneously dispersed on the carbon support in with Pt particle size of $3.06 \mathrm{~nm}$. (Fig.3c\&3c') Figure(3e\& 3e') show TEM images of $\mathrm{Pt}-\mathrm{CeO}_{2} / \mathrm{C}$ and $\mathrm{Pt}-\mathrm{CeO}_{2} / \mathrm{C}-1$, respectively. The addition of $\mathrm{CeO}_{2}$ to $\mathrm{Pt} / \mathrm{C}$ using a single reducing agent of (EG)during the reduction step decreases the resultant Pt particle size $(2.50 \mathrm{~nm})$ while using mixed reducing agent $\left(\mathrm{EG}+\mathrm{NaBH}_{4}\right)$ increases $\mathrm{Pt}$ particle size $(2.78 \mathrm{~nm})$ which in agreement with the fact that; the used reducing agent strongly affects morphology and ORR activity of nano carbon supported electrocatalysts. Using different reducing agents, namely; ethylene glycol (EG), borohydride $\left(\mathrm{NaBH}_{4}\right)$ and formaldehyde $(\mathrm{HCHO})$ resulted in producing electrocatalysts with different particle size. The method with (EG) has resulted in the smallest mean particle sizes in the range between 4.6 and $6.6 \mathrm{~nm}$, the electrocatalyst based on $\mathrm{NaBH}_{4}$ provided the mean particle size ranging between 4.6 and $13.3 \mathrm{~nm}$, while that based on HCHO has showed a mean particle size in the range $8.8-22.9 \mathrm{~nm}[51]$. When $\mathrm{CeO} 2$ is added to $\mathrm{Pt} / \mathrm{C}$ in $\mathrm{Pt}_{-}-\mathrm{CeO}_{2} / \mathrm{C}$ electrocatalyst as in Figs. 3c,c' aggregated particles are shown, this could be attributed to the tendency of Pt$\mathrm{CeO}_{2}$ nanoparticles to form agglomerates[52]. TEM images of $\mathrm{Pt}-\mathrm{ZrO}_{2} / \mathrm{C}$ electrocatalystare represented in Figs. (3d\&3d') Pt particle size was found to be $3.49 \mathrm{~nm}$ which is little bit smaller than that of $\mathrm{Pt} / \mathrm{C}(3.57 \mathrm{~nm})$, this is somewhat similar to results obtained by Liu et al. who found that; The particle size for $\mathrm{Pt} / \mathrm{C}$ catalyst is $3.0 \mathrm{~nm}$ while that of $\mathrm{Pt}_{4} \mathrm{ZrO}_{2} / \mathrm{C}$ catalyst is $4.2 \mathrm{~nm}(31)$.

\section{Electrochemical characterization}

Electrochemical surface area (ECSA) evaluation

The electrochemical active surface area

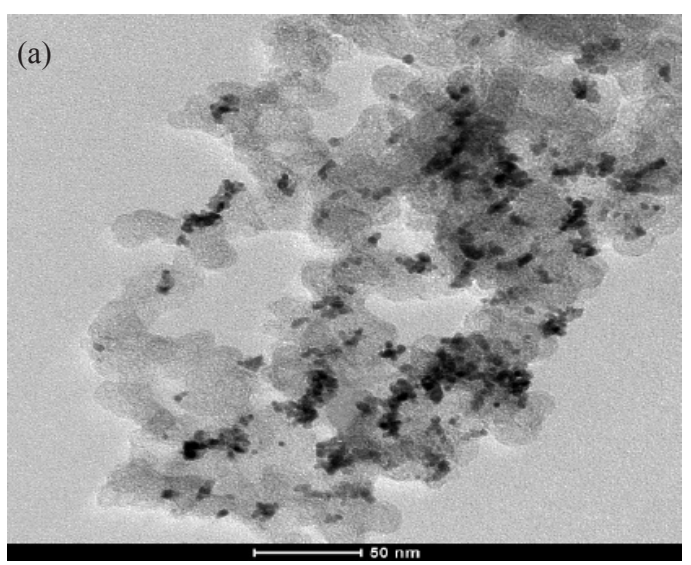

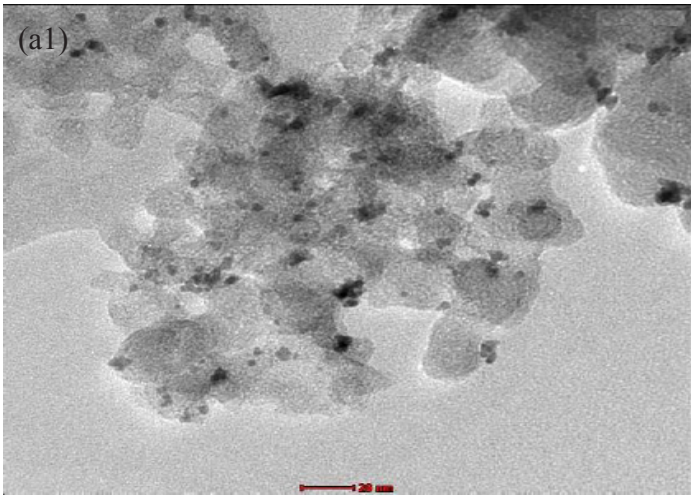
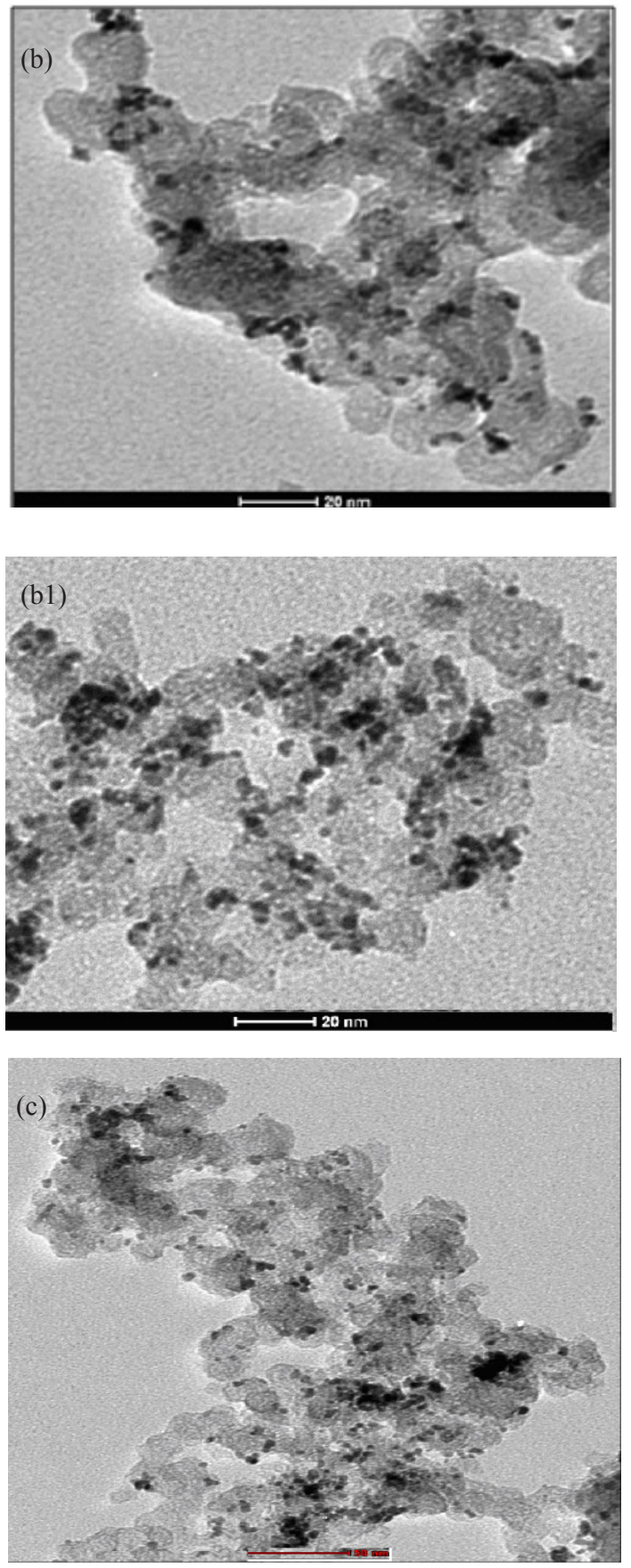

Egypt. J. Chem. 60, No.3 (2017) 

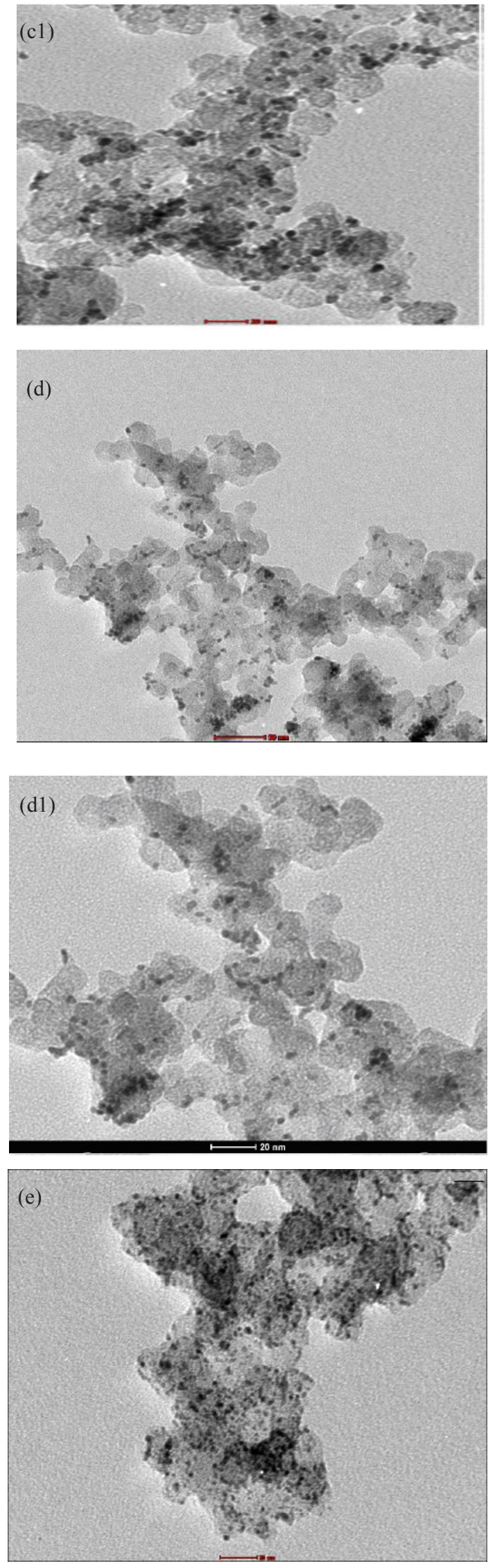

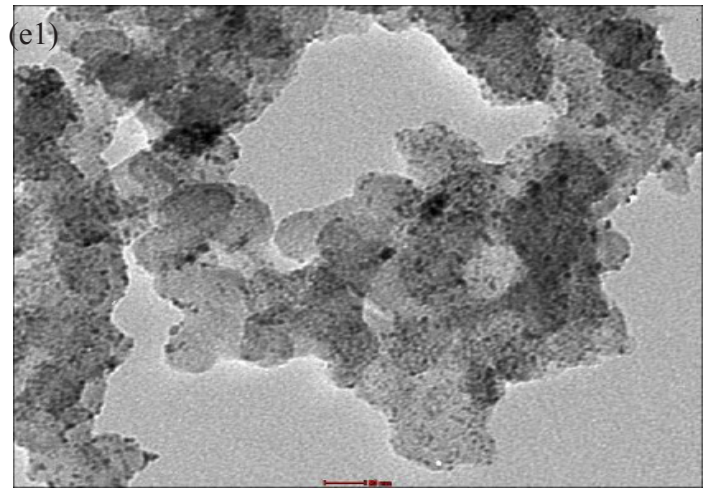

Fig. 3. TEM images of (a,a1) $\mathrm{Pt} / \mathrm{C}$, (b, b1) Pt-TiO $/ \mathrm{C}$, (c, c1) $\mathrm{Pt}-\mathrm{CeO}_{2} / \mathrm{C},(\mathrm{d}, \mathrm{d1}) \quad \mathrm{Pt}-\mathrm{ZrO}_{2} / \mathrm{C}$ and (e, e1) $\mathrm{Pt}-\mathrm{CeO}_{2} / \mathrm{C}-1$ electrocatalysts.

(ECSA) of a catalyst is calculated according to the following equation[53, 54]:

$$
\operatorname{ECSA}\left(m^{2} \mathrm{~g}^{-1}\right)=
$$

where $\mathrm{QH}\left(\mathrm{C} \mathrm{m}^{-2}\right)$ is the charge of hydrogen desorption, $[\mathrm{Pt}]\left(\mathrm{g} \mathrm{m}^{-2}\right)$ is the quantity of $\mathrm{Pt}$ loading on the electrode.

ECSA of the prepared electrocatalysts was estimated by integrating the voltammograms corresponding to hydrogen adsorption-desorption area. It is so obvious from Fig.4 that all Pt-MO $/ \mathrm{C}$ have higher ECSA values than that of $\mathrm{Pt} / \mathrm{C}$ as shown in Table 4 which is could be due to the presence of more active sites on the $\mathrm{Pt}-\mathrm{MO}_{\mathrm{x}} / \mathrm{C}$ surfaces than those on $\mathrm{Pt} / \mathrm{C}$ surface[55].

$\mathrm{Pt}-\mathrm{ZrO}_{2} / \mathrm{C}$ and $\mathrm{Pt}-\mathrm{CeO} 2 / \mathrm{C}$ electrocatalyst has the highest ECSA value among all studied electrocatalysts which are 69.60 and $46.93 \mathrm{~m}^{2} \mathrm{~g}^{-1}$ respectively, but in case of $\mathrm{Pt}-\mathrm{TiO}_{2} / \mathrm{C}$, it was noticed that; although its mass activity at $0.65 \mathrm{~V} /$ RHE is $-0.567 \mathrm{mAmg}^{-1}$ which is smaller than that of $\mathrm{Pt} / \mathrm{C}$ that equals $-2.11 \mathrm{mAmg}^{-1}$, it was found to have higher ECSA value, $32.90 \mathrm{~m}^{2} \mathrm{~g}^{-1}$ than that of $\mathrm{Pt} / \mathrm{C}$ which is $24.60 \mathrm{~m} 2 \mathrm{~g}-1$, this could be attributed to the smaller Pt size of $\mathrm{Pt}-\mathrm{TiO}_{2} / \mathrm{C}(3.06$ $\mathrm{nm})$ if it has been compared to $\mathrm{Pt} / \mathrm{C}(3.57 \mathrm{~nm})$ and better Pt dispersion as seen in Fig. (3a, 3a' and $3 \mathrm{~b}, 3 \mathrm{~b}^{\prime}$ ). This is in accordance with Gustavsson et al. who showed that the presence of $\mathrm{TiO}_{2}$ can either increase or decrease the ORR performance of Pt catalyst, depending on the sequence through which the thin films have been deposited which comes in accordance with the fact that; synthesis method has been found to make changes in the Pt electronic and geometric parameters[40].

Egypt. J. Chem. 60, No.3 (2017) 
On comparing the two prepared $\mathrm{Pt}-\mathrm{CeO}_{2} / \mathrm{C}$; namely: $\mathrm{Pt}-\mathrm{CeO}_{2} / \mathrm{C}$ and $\mathrm{Pt}-\mathrm{CeO}_{2} / \mathrm{C}-1$ we noticed that, changing the used reducing agent affects the behavior of the resultant electrocatalyst, as calculated from Equation 1, $\mathrm{Pt}-\mathrm{CeO}_{2} / \mathrm{C}$ showed higher ECSA value that equals $46.93 \mathrm{~m}^{2} \mathrm{~g}^{-1}$ than that of $\mathrm{Pt}-\mathrm{CeO}_{2} / \mathrm{C}-1 ; 39.85 \mathrm{~m}^{2} \mathrm{~g}^{-1}$. Another observation is related to both $\mathrm{Pt}-\mathrm{ZrO}_{2}$ carbon supported electrocatalyst which is although it has large particle size $(3.49 \mathrm{~nm})$ it showed the highest ECSA and electrocatalytic activity, this could be explained by the fact that the difference in particle size is not huge to the extent that affects its catalytic activity if compared to results obtained by Oishi and Savadogo who synthesized Pd electro-catalyst monolayer on different single crystal substrates which was found to have wide range of particle sizes up to $92 \mathrm{~nm}$ with mean value of $18-20 \mathrm{~nm}[56]$.

Cyclic voltammetry results

Cyclic Voltammograms curves (CVs) in oxygen saturated solution were recorded in the

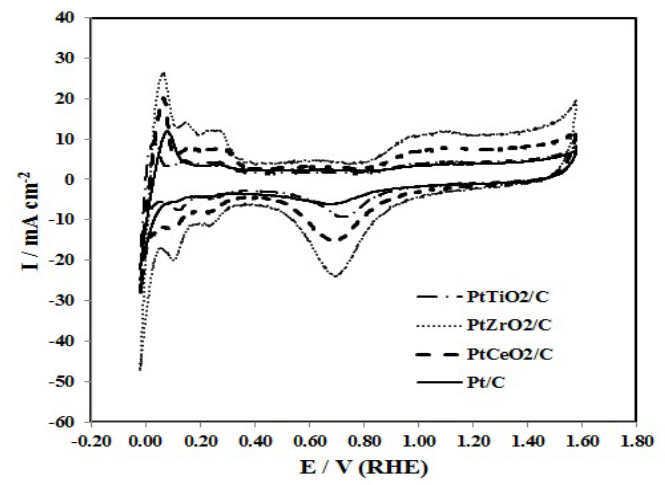

Fig. 4. 30th C.V.s of $\mathrm{Pt} / \mathrm{C}$ and different Pt-MOx/C electrocatalysts in $0.5 \mathrm{M} \mathrm{H}_{2} \mathrm{SO}_{4}$ solution at $25{ }^{\circ} \mathrm{C}$; scan rate: $50 \mathrm{mVs}^{-1}$

potential range from -1.0 to $1199 \mathrm{mV} / \mathrm{RHE}$. The results of $\mathrm{Pt} / \mathrm{C}$ and $\mathrm{Pt}-\mathrm{MOx} / \mathrm{C}$ catalysts are presented in Fig. 5, the voltammograms shape is the typical shape of that of $\mathrm{Pt}$ nanoparticles in acid

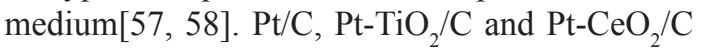
electrocatalysts show:

- The characteristic H adsorption- desorption peak at $0.05-0.3 \mathrm{~V} / \mathrm{RHE}$ while that for Pt$\mathrm{ZrO}_{2} / \mathrm{C}$ lies at $0.05-0.4 \mathrm{~V} / \mathrm{RHE}$.

- $\mathrm{Pt}$ oxide formation-reduction peaks at $0.85 / 0.60 \mathrm{~V} / \mathrm{RHE}$.

- It could be easily noticing that; $\mathrm{Pt}-\mathrm{ZrO}_{2} / \mathrm{C}$

Egypt. J. Chem. 60, No.3 (2017) and $\mathrm{Pt}-\mathrm{CeO}_{2} / \mathrm{C}$ have the highest Pt oxidationreduction peaks among the prepared electrocatalysts

\section{Study of oxygen reduction with $R D E$}

Figure6 represents linear sweep voltammograms (LSVs) of $\mathrm{Pt} / \mathrm{C}$ and $\mathrm{Pt}-\mathrm{MOx} / \mathrm{C}$ where $(\mathrm{M}=\mathrm{Ti}, \mathrm{Ce}$ or $\mathrm{Zr}$ ), it is obvious that, all prepared $\mathrm{Pt}-\mathrm{MO}_{\mathrm{x}} / \mathrm{C}$ electrocatalysts have higher activity towards ORR than $\mathrm{Pt} / \mathrm{C}$ except for $\mathrm{Pt}-\mathrm{TiO}_{2} / \mathrm{C}$. Moreover $\mathrm{Pt}-\mathrm{ZrO} / \mathrm{Chas}$ the highest mass activity values at $0.65 \mathrm{~V} / \mathrm{RHE}$ that equals $-9.75 \mathrm{mAmg}^{-1}$ i.e. the best activity towards ORR when it was compared with the other catalysts, this is because $\mathrm{ZrO}_{2}$ was found to have fairly high oxygen storage capacity, which enlarges the oxygen concentration at the catalyst surface, and achieves higher ORR activity with maintaining the catalyst at the same oxygen pressure[59].

Regarding forPt- $\mathrm{CeO}_{2} / \mathrm{C}$; it has high activity for ORR as seen from Fig. 6 and shows a good catalytic activity for ORR; $-2.240 \mathrm{mAcm}^{-2}$ at
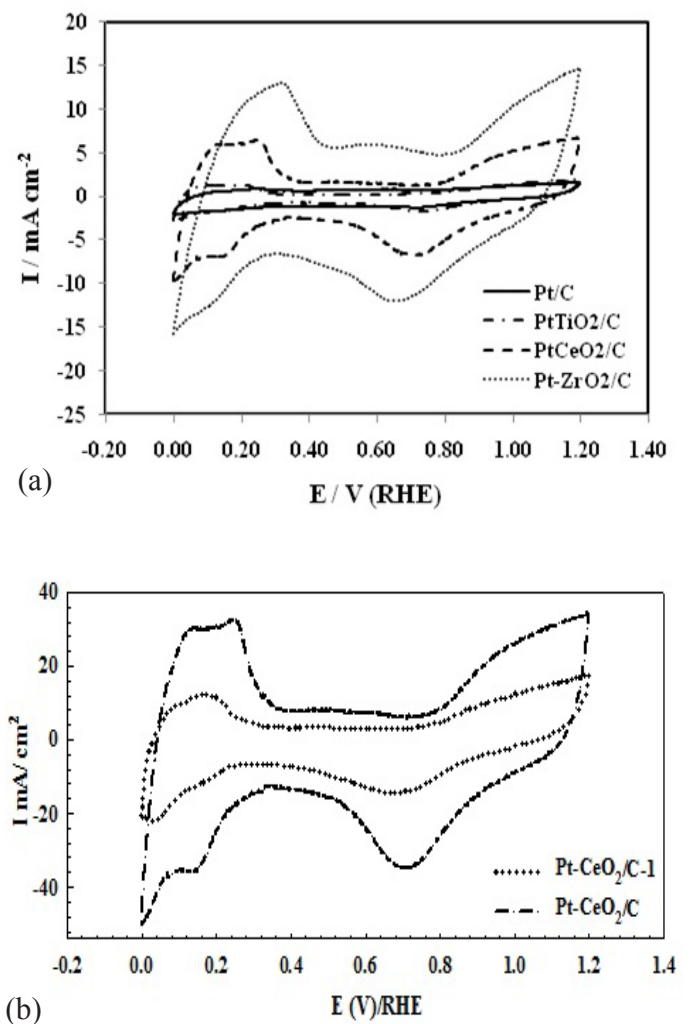

Fig. 5. Cyclic voltammograms of (a) $\mathrm{Pt} / \mathrm{C}$ and different $\mathrm{Pt}-\mathrm{MOx} / \mathrm{C}$, (b) $\mathrm{Pt}-\mathrm{CeO}_{2} / \mathrm{C}$ and $\mathrm{Pt}$ $\mathrm{CeO}_{2} / \mathrm{C}-1$ electrocatalysts in $\mathrm{O}_{2}$ saturated $0.5 \mathrm{M} \mathrm{H}_{2} \mathrm{SO}_{4}$ solution at $25^{\circ} \mathrm{C}$; scan rate: 50 $\mathrm{mVs}^{-1}$. 
$0.65 \mathrm{~V} / \mathrm{RHE}$ which is higher than that of $\mathrm{Pt} / \mathrm{C}(-$ $\left.1.262 \mathrm{mAcm}^{-2}\right)$ at the same potential value as seen in Table 4, this could be interpreted in the light of the fact that; $\mathrm{Pt}-\mathrm{CeO}_{\mathrm{x}}$ appears to have a characteristic system when compared to other $\mathrm{Pt}$-oxide composite catalysts; the active oxygen supplied from $\mathrm{CeO}_{2}$ to $\mathrm{Pt}$ surface contributed to the improvement of the ORR activity of the Pt$\mathrm{CeO}_{\mathrm{x}}$ cathode, so this noticed behaviour of high ORR activity of $\mathrm{Pt}-\mathrm{CeO}_{2} / \mathrm{C}$ may be improved by formation of $\mathrm{Pt}$ surface partially covered by amorphous $\mathrm{Ce}_{2} \mathrm{O}_{3}$ layer or may be due to the role of ceria layer in Pt oxide formation on Pt[60].

On evaluating the performance of mentioned electrocatalysts prepared using the mixed

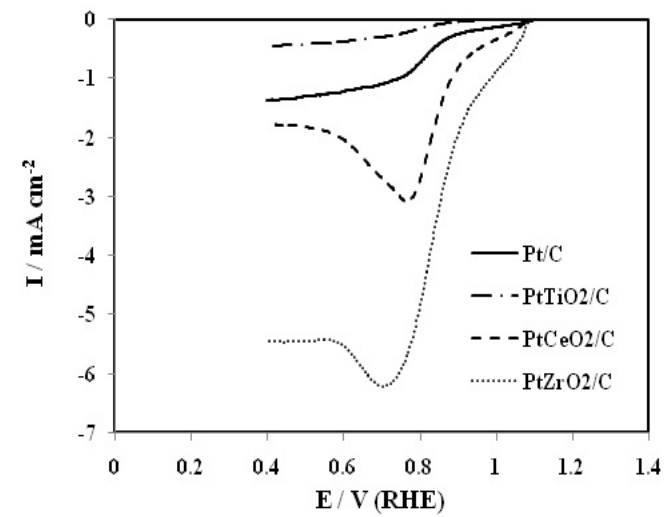

Fig. 6. RDE voltammograms of $\mathrm{Pt} / \mathrm{C}$ and different $\mathrm{Pt}-\mathrm{MOx} / \mathrm{C}$ electrocatalysts with electrode rotation rate at $2400 \mathrm{rpm}$ in $\mathrm{O}_{2}$ saturated $0.5 \mathrm{M} \mathrm{H}_{2} \mathrm{SO}_{4}$ solution at $25{ }^{\circ} \mathrm{C}$; scan rate: $10 \mathrm{mVs}^{-1}$.

reducing agent, it was found that $\mathrm{Pt}-\mathrm{CeO} 2 /$ Chas a higher potential value; $1097.9 \mathrm{mV} / \mathrm{RHE}$ than that of $\mathrm{Pt}-\mathrm{TiO} 2 / \mathrm{C} ; 967.9 \mathrm{mV} / \mathrm{RHE}$ at zero current, this big difference which equals 130.0 $\mathrm{mV}$ is related to the difference in mass activity value at $0.65 \mathrm{~V} / \mathrm{RHE}$ which is $-2.240 \mathrm{mAcm}-2$ for $\mathrm{Pt}-\mathrm{CeO} 2 / \mathrm{C}$ and $-0.340 \mathrm{mAcm}-2$ for $\mathrm{Pt}-\mathrm{TiO} 2 / \mathrm{C}$, meaning that increasing in the mass activity value of $\mathrm{Pt}-\mathrm{CeO} 2 / \mathrm{C} 6.588$ times as that of $\mathrm{Pt}-\mathrm{TiO} 2 / \mathrm{C}$. The case is different for $\mathrm{Pt}-\mathrm{ZrO} 2 / \mathrm{C}$ in which the mass activity value at $0.65 \mathrm{~V} / \mathrm{RHE}$ is the highest among the studied Pt-MOx/C; $-5.840 \mathrm{mAcm}-2$. The onset potential is known as the potential at which the current for oxygen reduction is first observed[61]. Here the onset potential value for $\mathrm{Pt}-\mathrm{ZrO} 2 / \mathrm{C}$ is the highest one among the studied electrocatalysts; $1041.2 \mathrm{mV} / \mathrm{RHE}$ indicating that the oxygen reduction catalytic activity of this electrocatalyst exceeds the other catalysts regarding to onset potential values; the higher onset potential values the higher catalytic activity towards ORR[62] as seen from Fig 6.

Figure $7(\mathrm{a}, \mathrm{b})$ shows the (LSVs) of ORR on the $\mathrm{Pt}-\mathrm{CeO}_{2} / \mathrm{C}$ and $\mathrm{Pt}-\mathrm{CeO}_{2} / \mathrm{C}-1$ electrodes respectively in $\mathrm{O}_{2}$ saturated $0.5 \mathrm{M} \mathrm{H}_{2} \mathrm{SO}_{4}$ solution with rotation rates ranging between 200-2400 rpm.
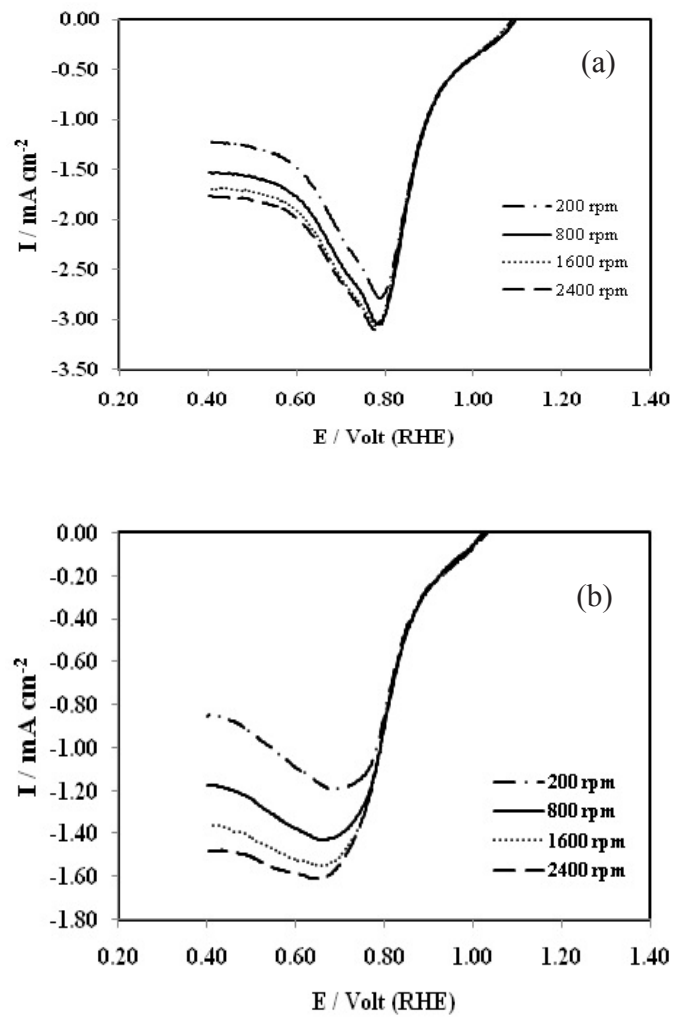

Fig. 7. RDE voltammograms of (a) $\mathrm{Pt}-\mathrm{CeO}_{2} / \mathrm{C}$, (b) Pt- $\mathrm{CeO}_{2} / \mathrm{C}-1$ with electrode rotation rates at 200, 800, 1600, and $2400 \mathrm{rpm}$. Electrode potential window $1.6 \mathrm{~V}$ to $0.4 \mathrm{~V} / \mathrm{RHE}$, scan rate $10 \mathrm{mVs}^{-1}$.

Clear performance differences between the two catalysts can be figured out by comparing the LSVs of a particular electrode rotation speed. It is very clear that there is an extrusive relation between cathodic current values and the rate of electrode rotation. The studied catalyst samples show the same ORR open circuit potential (around $1040 \mathrm{mV}$ for $\mathrm{Pt}-\mathrm{CeO}_{2} / \mathrm{C}-1$ and around $1080 \mathrm{mV}$ for Pt- $\mathrm{CeO}_{2} / \mathrm{C}$ ), generally this is in consistent with the expected behavior for ORR in aqueous acid medium catalyzed by $\mathrm{Pt}$ nanoparticles on carbon supports[60]. 
TABLE 2. Weight and atomic percentages of different elements forming $\mathrm{Pt} / \mathrm{C}$ and different $\mathrm{Pt}-\mathrm{MO} / \mathrm{C}$ electrocatalysts

\begin{tabular}{|c|c|c|c|c|c|c|c|c|c|c|}
\hline \multirow{2}{*}{ Element } & \multicolumn{2}{|c|}{$\mathrm{Pt} / \mathrm{C}$} & \multicolumn{2}{|c|}{$\mathrm{Pt}-\mathrm{TiO}_{2} / \mathrm{C}$} & \multicolumn{2}{|c|}{$\mathrm{Pt}-\mathrm{CeO}_{2} / \mathrm{C}$} & \multicolumn{2}{|c|}{$\mathrm{Pt}-\mathrm{ZrO}_{2} / \mathrm{C}$} & \multicolumn{2}{|c|}{$\mathrm{Pt}-\mathrm{CeO}_{2} / \mathrm{C}-1$} \\
\hline & Weight $\%$ & Atomic\% & Weight $\%$ & Atomic\% & Weight $\%$ & Atomic\% & Weight $\%$ & Atomic\% & Weight $\%$ & Atomic\% \\
\hline C K & 63.97 & 96.65 & 42.82 & 86.70 & 44.60 & 89.58 & 37.69 & 86.26 & 67.83 & 84.19 \\
\hline O K & - & - & 2.98 & 4.54 & 2.27 & 3.42 & 2.80 & 4.80 & 15.38 & 14.34 \\
\hline Pt M & 36.03 & 3.35 & 48.96 & 6.10 & 44.29 & 5.48 & 56.03 & 7.89 & 10.39 & 0.79 \\
\hline Ti K & - & - & 5.24 & 2.66 & - & - & & - & - & - \\
\hline $\mathrm{Ce} \mathrm{L}$ & - & - & - & - & 8.84 & 1.52 & - & & 6.40 & 0.68 \\
\hline $\mathrm{ZrL}$ & - & - & - & - & & & 3.48 & 1.05 & - & - \\
\hline
\end{tabular}

TABLE 3. Particle size values of Pt/C and different Pt-MO $/ \mathrm{C}$ electrocatalysts according to TEM analysis.

\begin{tabular}{cc}
\hline Electrocatalyst & Particle size $/ \mathbf{n m}$ \\
\hline $\mathbf{P t} / \mathbf{C}$ & 3.57 \\
\hline $\mathbf{P t}-\mathrm{TiO}_{2} / \mathrm{C}$ & 3.06 \\
\hline $\mathbf{P t}-\mathrm{CeO}_{2} / \mathbf{C}$ & 2.78 \\
\hline $\mathbf{P t}-\mathrm{ZrO}_{2} / \mathrm{C}$ & 3.49 \\
\hline $\mathbf{P t}-\mathrm{CeO}_{2} / \mathbf{C}-\mathbf{1}$ & 2.50 \\
\hline
\end{tabular}

TABLE 4. Electrochemical parameters and electrochemical surface area values obtained from LSVs and CVs of $\mathrm{Pt} / \mathrm{C}$ and $\mathrm{Pt}-\mathrm{Mo}_{\mathrm{x} /} \mathrm{C}$ electrocatalysts $0.5 \mathrm{MH}_{2} \mathrm{SO}_{4}$ solution.

\begin{tabular}{ccccc}
\hline Electrocatalysts & $\begin{array}{c}\text { Open circuit pot. }[\mathrm{mV} / \mathrm{RHE}] \\
\text { at } \mathbf{0} \text { current }\end{array}$ & $\begin{array}{c}\text { Onset ORR [mV/ } \\
\mathrm{RHE}]\end{array}$ & $\begin{array}{c}\text { ECSA } \\
{\left[\mathbf{m}^{2} \mathbf{g}^{-1}\right]}\end{array}$ & $\begin{array}{c}\text { Current density at } \\
\mathbf{6 5 0} \mathbf{~ m V / R H E}\end{array}$ \\
\hline $\mathbf{P t} / \mathbf{C}$ & 899.5 & 830.1 & 24.60 & -1.262 \\
\hline $\mathbf{P t}-\mathrm{TiO}_{\mathbf{2}} / \mathbf{C}$ & 967.9 & 790.5 & 32.90 & -0.34 \\
\hline $\mathbf{P t}-\mathrm{CeO}_{2} / \mathbf{C}$ & 1097.9 & 931.4 & 46.93 & -2.240 \\
\hline $\mathbf{P t}-\mathrm{ZrO}_{\mathbf{2}} / \mathbf{C}$ & 801.0 & 1041.2 & 69.60 & -5.840 \\
\hline
\end{tabular}

The increase in the diffusion limiting current in the RDE measurement is directly proportional to the rotation speed. The limiting current densities of Pt- $\mathrm{CeO}_{2} / \mathrm{C}$ increased from 1.25 to 1.80 $\mathrm{mAcm}^{-2}$ while that of $\mathrm{Pt}-\mathrm{CeO}_{2} / \mathrm{C}-1$ increased from 0.82 to $1.55 \mathrm{mAcm}^{-2}$ as the rotation speeds were increased from 200 to $2400 \mathrm{rpm}$, this behavior could be explained by the fact that; higher rotation speeds leads to faster oxygen flux at the electrode surface and hence generating higher currents.

Hydrated oxide reduction produced by applying a reducing agent. Typical reducing agents are $\mathrm{H}_{2}$ [63] where strength of reduction is controlled by temperature $[64,65]$ and $\mathrm{NaBH}_{4}$ [66] which have strong reduction strength at room temperature

Comparing $\mathrm{Pt}-\mathrm{CeO}_{2} / \mathrm{C}$ and $\mathrm{Pt}-\mathrm{CeO}_{2} \mathrm{C}-1$ in Fig. (7a, 7b) we can easily notice that, for 2400 rpm, Pt- $\mathrm{CeO}_{2} / \mathrm{C}$ had a higher current density value at $0.65 \mathrm{~V} / \mathrm{RHE} ;-2.240 \mathrm{mAcm}^{-2}$ than that of $\mathrm{Pt}-\mathrm{CeO}_{2} / \mathrm{C}-1$ that equals to- $1.597 \mathrm{mAcm}^{-2}$, this could be related to the fact that, smaller particle sized electrocatalysts produced from using single reducing agent may tend to agglomerate and hence reduce the activity of the whole electrocatalysts, hence the oxide reduction extent in the preparation method affects the $\mathrm{Pd}$ and $\mathrm{Au}$ performance towards the ORR which is related to the catalyst synthesis procedures [67-71].

From the comparison of the LSVs recorded for both $\mathrm{Pt}-\mathrm{CeO} 2$ on Carbon catalysts at 2400 rpm we can easily also observe the differences in the open circuit potential,limiting currentand half wave potential values. The open circuit potential is higher in case of $\mathrm{Pt}-\mathrm{CeO}_{2} / \mathrm{C}$ catalyst; $1097.9 \mathrm{mV} / \mathrm{RHE}$ than in case of $\mathrm{Pt}-\mathrm{CeO}_{2} / \mathrm{C}-1$; $-1055.3 \mathrm{mV} / \mathrm{RHE}$, faster ORR is observed in the whole potential window for $\mathrm{Pt}-\mathrm{CeO}_{2} / \mathrm{C}$ than on $\mathrm{Pt}-\mathrm{CeO}_{2} / \mathrm{C}-1$ catalyst. The half wave potential of $\mathrm{Pt}-\mathrm{CeO}_{2} / \mathrm{C}$ was shifted to about $100 \mathrm{mV}$ in the positive side compared to $\mathrm{Pt}-\mathrm{CeO}_{2} / \mathrm{C}-1$. Similarly, the limiting current of $\mathrm{Pt}-\mathrm{CeO}_{2} / \mathrm{C}$ catalyst is higher by about $300 \mathrm{~mA}$ (regardless to the sign) compared to $\mathrm{Pt}-\mathrm{CeO}_{2} / \mathrm{C}-1$. The favorable shifts in the open circuit, half wave potential and limiting current regions equivalent to the electrode of Pt$\mathrm{CeO} 2 / \mathrm{C}$ can be attributed to the enhanced ORR activity. It was found that the difference in the limiting currents for the two electrocatalysts may 
be due to the difference of oxygen diffusion at both of them[72]. It is also found thatPt- $\mathrm{CeO}_{2} / \mathrm{C}$ $(8.84 \mathrm{Ce} \%)$ had higher onset potential and limiting current than $\mathrm{Pt}-\mathrm{CeO}_{2} / \mathrm{C}-1(6.40 \mathrm{Ce} \%)$ which is in accordance with Kang et al.[73]

Oxygen reduction mechanism of $\mathrm{Pt}-\mathrm{CeO} 2 / \mathrm{C}$ and $\mathrm{Pt}-\mathrm{CeO}_{2} / \mathrm{C}-1$ has been evaluated using the Koutecky-Levichequation to determine the number of electrons transferred per $\mathrm{O}_{2}$ molecule.

$$
-\frac{1}{\mathrm{I}}=-\frac{1}{\mathrm{I}_{\mathrm{k}}}+\frac{1}{0.62 \mathrm{n} \mathrm{FAD}^{1 / 2} \mathrm{cv}^{-1 / 6} \omega^{1 / 2}}(2)
$$

where $I_{k}$ is the kinetic current; $\omega$ is the rotation rate; $\mathrm{n}$ is the number of electrons involved in the reaction; F is Faraday constant; $A$ is the geometric area of the disk electrode; $\mathrm{D}$ and $\mathrm{c}$ are the diffusion coefficient of dissolved oxygen and the concentration of dissolved oxygen in $0.5 \mathrm{M} \mathrm{H}_{2} \mathrm{SO}_{4}$, respectively; $\mathrm{v}$ is the kinematic viscosity of the electrolyte.

Figure 8 a, b represents Koutecky-Levitch (-1/I versus $\left.\omega^{-1 / 2}\right)$ plots for the ORR on Pt- $\mathrm{CeO}_{2} / \mathrm{C}$ and $\mathrm{Pt}-\mathrm{CeO}_{2} / \mathrm{C}-1$ electrodes respectively at electrode potential range from $0.2 \mathrm{~V}-0.5 \mathrm{~V}$ vs. RHE in $0.5 \mathrm{M} \mathrm{H}_{2} \mathrm{SO}_{4}$. The linearity and the parallism of these plots indicate first-order kinetics with respect to molecular oxygen[74]. The calculation of $\mathrm{n}$ was performed using the values: $\mathrm{F}=96,485$ $\mathrm{Cmol}^{-1} ; \mathrm{A}=0.196 \mathrm{~cm}^{2} ; \mathrm{D}=1.93 \times 10^{-5} \mathrm{~cm}^{2} \mathrm{~s}^{-1} ; \mathrm{c}$ $=1.13 \times 10^{-6} \mathrm{~mol} \mathrm{~cm}{ }^{-3} ; \mathrm{v}=9.5 \times 10-3 \mathrm{~cm}^{2} \mathrm{~s}^{-1}[75]$. Intercept different values at the $y$-axis indicate the existence of different kinetic constants at different electrode potentials while the non-zero values of the intercepts imply that the ORR is not controlled solely by diffusion [76].

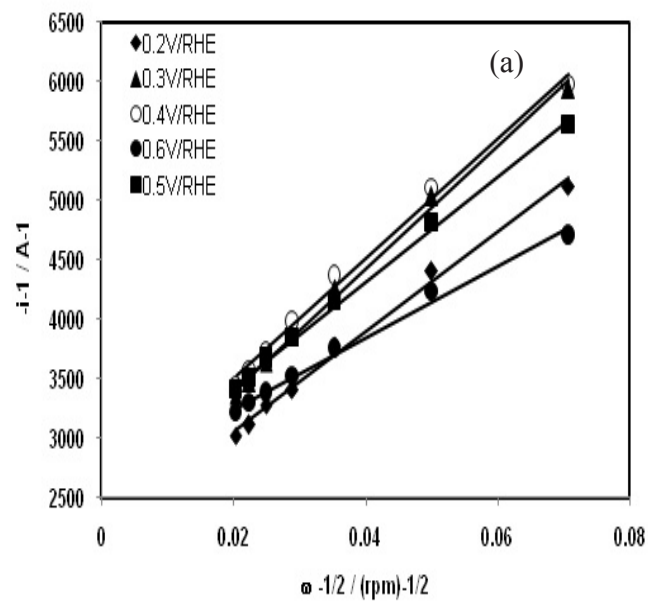

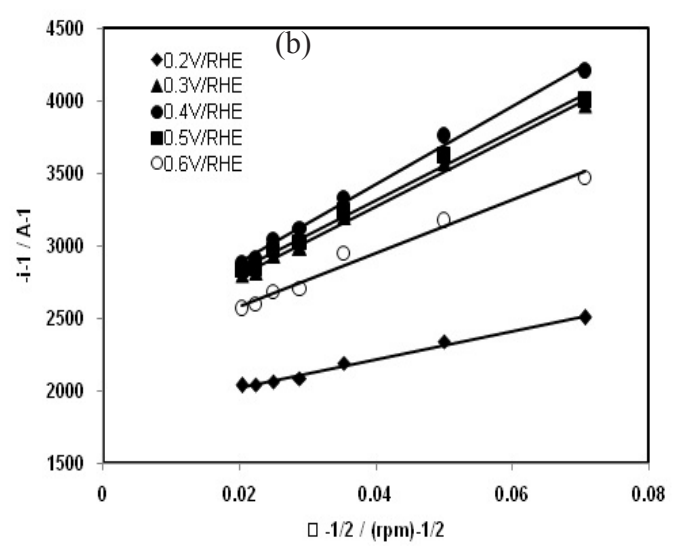

Fig. 8.Koutecky-Levichplot drawn at different potentials for (a) $\mathrm{Pt}-\mathrm{CeO}_{2} / \mathrm{C}$, b) $\mathrm{Pt}-\mathrm{CeO}_{2} / \mathrm{C}-1$ in $\mathrm{O}_{2}$-saturated $0.5 \mathrm{M}$ sulphuric acid solution at $2400 \mathrm{rpm}$, scan rate $10 \mathrm{mVs}^{-1}$.

\section{Conclusion}

$\mathrm{Pt}-\mathrm{MO}_{\mathrm{x}} / \mathrm{C}$ electrocatalysts have been prepared through two steps. The first step involves the synthesis of $\mathrm{MOx} / \mathrm{C}$ powders via solid state reaction under intermittent microwave heating, while the second step is platinum loading on $\mathrm{MO}_{\mathrm{x}} / \mathrm{C}$ surfaces using ethylene glycol or a mixture of ethylene glycol and sodium borohydride as the reducing agent.

- The preparation method of the electrocatalysts is found to affect their behaviour towards ORR.

- $\mathrm{Pt}-\mathrm{CeO}_{2} / \mathrm{C}$ and $\mathrm{Pt}-\mathrm{ZrO}_{2} / \mathrm{C}$ have the highest activity for oxygen reduction among the studied electrocatalysts and also higher than that of prepared $\mathrm{Pt} / \mathrm{C}$ in acid medium.

- Changing the used reducing agent was found to affect the electrocatalytic efficiency and electrochemical surface area of the resultant electrocatalyst.

- $\mathrm{Pt}-\mathrm{CeO}_{2} / \mathrm{C}$ and $\mathrm{Pt}-\mathrm{CeO}_{2} / \mathrm{C}-1$ showed firstorder kinetics with respect to molecular oxygen with oxygen reduction reaction not controlled solely by diffusion.

\section{References}

1. Jiang, T., Brisard, G.M., Determination of the kinetic parameters of oxygen reduction on copper using a rotating ring single crystal disk assembly (RRDCu(hkl)E). Electrochim Acta. 52, 4487-96, (2007).

2. Marković, N.M., Schmidt, T.J., Stamenković, V., Ross, P.N., Oxygen reduction reaction on $\mathrm{pt}$ and $\mathrm{pt}$ bimetallic surfaces: A selective review. Fuel Cells. 1, 105-16, (2001). 
3. Neergat, M., Shukla, A.K., Gandhi, K.S., Platinumbased Alloys as oxygen-reduction Catalysts for Solid-Polymer-Electrolyte Direct Methanol Fuel Cells. J. Appl Electrochem. 31, 373-8. (2001).

4. Toda, T., Igarashi, H., Uchida, H., Watanabe, M., Enhancement of the Electroreduction of Oxygen on Pt Alloys with Fe, Ni, and Co. J. Electrochem Soc. 146, 3750-6.(1999).

5. Li, W., Zhou, W., Li, H., Zhou, Z., Zhou, B., Sun, G., et al. Nano-stuctured $\mathrm{Pt}-\mathrm{Fe} / \mathrm{C}$ as cathode catalyst in direct methanol fuel cell. Electrochim Acta. 49, 1045-55. (2004).

6. Ehteshami, S.M.M., Chan, S.H., A review of electrocatalysts with enhanced $\mathrm{CO}$ tolerance and stability for polymer electrolyte membarane fuel cells. Electrochim Acta. 93, 334-45. (2013).

7. Liaxg, C.C., Juliard, A.L., The overpotential of oxygen reduction at platinum electrodes. $J$ Electroanal Chem. 9, 390-4. (1965).

8. Rosalbino, F., Delsante, S., Borzone, G., Angelini, E., Electrocatalytic behaviour of $\mathrm{Co}-\mathrm{Ni}-\mathrm{R}$ $(\mathrm{R}=$ Rare earth metal) crystalline alloys as electrode materials for hydrogen evolution reaction in alkaline medium. Int J. Hydrogen Energy. 33, p. 6696-703. (2008).

9. Jaks, M.M., Hypo - hyper- d -electronic interactive nature of synergism in catalysis and electrocatalysis for hydrogen reactions. 45, 408599. (2000).

10. Neophytides, S.G., Murase, K., Zafeiratos, S., Papakonstantinou, G., Paloukis, F.E., Krstajic, N.V., et al. Composite hypo-hyper-d-intermetallic and interionic phases as supported interactive electrocatalysts. J. Phys Chem B. 110, p. 3030-42. (2006)

11. Jakšić, M.M., Hypo-hyper-d-electronic interactive nature of interionic synergism in catalysis and electrocatalysis for hydrogen reactions. Int $J$. Hydrogen Energy. 26, p. 559-78. (2001).

12. Wang, X., Xu, W., Zhou, X., Lu, T., Xing, W., Liu, $\mathrm{C}$., et al. $\mathrm{PtCeOx} / \mathrm{C}$ as a novel methanol-tolerant electrocatalyst of oxygen reduction for direct methanol fuel cells. J. Solid State Electrochem. 13, 1449-53. (2009).

13. $\mathrm{Xu}, \mathrm{F} ., \mathrm{Xu}, \mathrm{R} ., \mathrm{Mu}, \mathrm{S} .$, Enhanced $\mathrm{SO}_{2}$ and $\mathrm{CO}$ poisoning resistance of $\mathrm{CeO}_{2}$ modified $\mathrm{Pt} / \mathrm{C}$ catalysts applied in PEM fuel cells. Electrochim Acta. 112, 304-9. (2013).

14. Lim, D.H., Lee, W.D., Choi, D.H., Lee, H.I., Effect of ceria nanoparticles into the $\mathrm{Pt} / \mathrm{C}$ catalyst as cathode material on the electrocatalytic activity and durability for low-temperature fuel cell. Appl Catal B Environ. 94, 85-96. (2010).
15. He, Q., Mukerjee, S., Zeis, R., Parres-Esclapez, S., Illán-Gómez, M.J., Bueno-Lópeza., Enhanced Pt stability in $\mathrm{MO}_{2}(\mathrm{M}=\mathrm{Ce}, \mathrm{Zr}$ or $\mathrm{Ce} 0.9 \mathrm{Zr} 0.1)$ promoted $\mathrm{Pt} / \mathrm{C}$ electrocatalysts for oxygen reduction reaction in PAFCs. Appl Catal A Gen. 381, 54-65. (2010).

16. Gu, D.M., Chu, Y.Y., Wang, Z.B., Jiang, Z.Z., Yin, G.P., Liu, Y., Methanol oxidation on $\mathrm{Pt} / \mathrm{CeO}_{2}-\mathrm{C}$ electrocatalyst prepared by microwave-assisted ethylene glycol process. Appl Catal B Environ. 102, 9-18.(2011).

17. Scibioh, M.A., Kim, S.K., Cho, E.A., Lim, T.H., Hong, S.A., Ha, H.Y., Pt-CeO $/ \mathrm{C}$ anode catalyst for direct methanol fuel cells. Appl Catal B Environ. 84, 773-82. (2008).

18. Xu, C., Shen, P.K., Electrochamical oxidation of ethanol on Pt-CeO $/ \mathrm{C}$ catalysts. J. Power Sources. 142, 27-9. (2005).

19. Xu, C., Zeng, R., Shen, P.K., Wei, Z., Synergistic effect of $\mathrm{CeO}_{2}$ modified Pt/C catalysts on the alcohols oxidation. Electrochim Acta. 51, 1031-5. (2005).

20. Peng, W., Zhao, L., Zhang, C., Yan, Y., Xian, Y., Controlled growth cerium oxide nanoparticles on reduced grapheme oxide for oxygen catalytic reduction. Electrochim Acta. 191, 669-76, (2016).

21. Guo, X., Guo, D.J., Qiu, X.P., Chen, L.Q., Zhu, W.T., Excellent dispersion and electrocatalytic properties of Pt nanoparticles supported on novel porous anatase $\mathrm{TiO}_{2}$ nanorods. J. Power Sources. 194, 281-5. (2009).

22. Selvaganesh, S.V., Selvarani, G., Sridhar, P., Pitchumani, S., Shuklaa., K., A durable PEFC with carbon-supported Pt-TiO[sub 2] cathode: A cause and effect study. J. Electrochem Soc. 157, B1000. (2010).

23. Ruiz-Camacho, B., Valenzuela M.A., GonzálezHuerta, R.G., Suarez-Alcantara, K., Canton, S.E., Pola-Albores, F., Electrochemical and XAS investigation of oxygen reduction reaction on

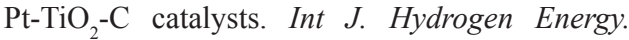
38,12648-56. (2013).

24. De Tacconi, N.R., Chenthamarakshan, C.R., Rajeshwar, K., Lin, W.Y., Carlson, T.F., Nikiel L, et al. Photocatalytically generated $\mathrm{P} t \mathrm{C}-\mathrm{TiO}[\mathrm{sub} 2]$ electrocatalysts with enhanced catalyst dispersion for improved membrane durability in polymer electrolyte fuel cells. J. Electrochem Soc. 155, B1102. (2008)

25. Jeon, M.K., McGinn, P.J., Effect of Ti addition to $\mathrm{Pt} / \mathrm{C}$ catalyst on methanol electro-oxidation and oxygen electro-reduction reactions. J. Power Sources. 195, 2664-8. ( 2010). 
26. Mukerjee, S., Role of structural and electronic properties of $\mathrm{Pt}$ and $\mathrm{Pt}$ alloys on electrocatalysis of oxygen reduction. J. Electrochem Soc. 142, B1409. (1995).

27. Hayashi, T., Ishihara, A, Nagai, T., Arao, M., Imai, H., Kohno, Y., Matsuzawa, K., Mitsushima, S., Ota, K., Temperature dependence of oxygen reduction mechanism on a titanium oxide-based catalyst made from oxy-titanium tetra- pyrazinoporphyrazine using carbon nano-tubes as support in acidic solution. Electrochim Acta. 209, p.1-6, (2016).

28. Ando, F., Tanabe, T., Gunji, T., Tsuda, T., Kaneko, S., Takeda, T., Ohsaka, T., Matsumoto, F., Improvement of ORR activity and durability of $\mathrm{Pt}$ electrocatalyst nanoparticles anchored on $\mathrm{TiO}_{2}$ /cupstacked carbon nanotube in acidic aqueous media. Electrochim Acta. 232, 404-13(2017).

29. Esfahani, R.A.M., Vankova, S.K., Videla, A.H.A.M., Specchia, S., Innovative carbon-free low content Pt catalyst supported on Mo-doped titanium suboxide $\left(\mathrm{Ti}_{3} \mathrm{O}_{5}-\mathrm{Mo}\right)$ for stable and durable oxygen reduction reaction. Appl Catal B Environ. 201, 419-29, (2017).

30. Wang, R., Wang, K., Wang, H., Wang, Q., Key, J., Linkov, V., et al. Nitrogen-doped carbon coated $\mathrm{ZrO}_{2}$ as a support for Pt nanoparticles in the oxygen reduction reaction. Int J. Hydrogen Energy. 38, 5783-8. (2013).

31. Liu, G., Zhang, H., Zhai, Y., Zhang, Y., Xu, D., Shao, Z., $\mathrm{Pt}_{4} \mathrm{ZrO}_{2} / \mathrm{C}$ cathode catalyst for improved durability in high temperature PEMFC based on $\mathrm{H}_{3} \mathrm{PO}_{4}$ doped PBI. Electrochem Commun. 9, 13541. (2007).

32. Shahid, M.M., Rameshkumar, P, Basirun, W.J., Ching, J.J., Huang, N.M., Cobalt oxide nanocubes interleaved reduced graphene oxide as an efficient electrocatalyst for oxygen reduction reaction in alkaline medium. Electrochim Acta. 237, 61-8, (2017).

33. Wang, Q., Hu, W., Huang, W., Nitrogen doped graphene anchored cobalt oxides efficiently bifunctionally catalyze both oxygen reduction reaction and oxygen revolution reaction. Int $J$. Hydrogen Energy. 42, p. 5899-907, (2017).

34. Chen, W., Zhao, J., Yang, L.J., Liu, Z., Microwave heated polyol synthesis of carbon nanotubes supported Pt nanoparticles for methanol electrooxidation. Materials Chemistry and Physics. 91, 124-9, (2005).

35. Zhao, J., Chen, W., Zheng, Y., Li, X., Xu, Z., Microwave polyol synthesis of $\mathrm{Pt} / \mathrm{C}$ catalysts with size controlled Pt particles for methanol electrocatalytic oxidation. Journal of Material Science. 41, 5514-8, (2006).
36. Suguru, Y., Masahito, S., Microwave-assisted chemical modification of carbon nanohorns: oxidation and Pt deposition. Chemical Physics Letters. 433, p. 97-100, (2006).

37. Peuchert, M., Yoneda, T., Betta, R., Boudart, M., Oxygen reduction on small supported platinum particles. Journal of Electrochemica Society. 5, 133, 944 -7, (1986).

38. Kinoshita, K., Particle size effects for oxygen reduction on highly dispersed platinum in acid electrolytes. Journal of the Electrochemical Society. 3, 137, 845-8, (1990).

39. Takasu, Y., Itaya, H., Iwazaki, T., Miyoshi, R., Ohnuma, T., Sugimoto, W., Murakami, Y., Size effects of ultrafine Pt-Ru particles on the electrocatalytic oxidation of methanol. Chemical Communications. 2001, 341-2, (2001).

40. Meng, H., Shen, P.K., The beneficial effect of the addition of tungsten carbides to Pt catalysts on the oxygen electroreduction. Chem Commun. 41, 35 4408-10, (2005).

41. Tian, Z.Q., Xie, F.Y., Shen, P.K., Preparation of high loading Pt supported on carbon by on-site reduction. J. Mater Sci. 39, 4: p. 1507-9, (2004).

42. Shen, P.K., Tian, Z., Performance of highly dispersed $\mathrm{Pt} / \mathrm{C}$ catalysts for low temperature fuel cells. Electrochim Acta. 49, 19: p.3107-11, (2004).

43. Xu, C., Shen, P.K., Novel Pt/ $/ \mathrm{CeO}_{2} / \mathrm{C}$ catalysts for electrooxidation of alcohols in alkaline media. Chem Commun. 40, 19: 2238-9, (2004).

44. Lim, D.H., Lee, W.D., Choi, D.H., Kwon, H.H., Lee, H.I., The effect of cerium oxide nanoparticles on a $\mathrm{Pt} / \mathrm{C}$ electrocatalyst synthesized by a continuous two-step process for low-temperature fuel cell. Electrochem Commun. 10, 592-6. (2008).

45. Justin, P., Hari, K., C., P., Ranga, R., G., High performance $\mathrm{Pt}-\mathrm{Nb}_{2} \mathrm{O}_{5} / \mathrm{C}$ electrocatalysts for methanol electrooxidation in acidic media. Appl Catal B Environ. 100, 510-5. (2010).

46. Justin, P., Rao, G.R., Enhanced activity of methanol electro-oxidation on $\mathrm{Pt}-\mathrm{V}_{2} \mathrm{O}_{5} / \mathrm{C}$ catalysts. Catal Today. 141, 138-43. (2009).

47. Zhou, C., Wang, H., Peng, F., Liang, J., Yu, H., Yang, J., $\mathrm{MnO}_{2} / \mathrm{CNT}$ supported $\mathrm{Pt}$ and $\mathrm{PtRu}$ nanocatalysts for direct methanol fuel cells. Langmuir. 25, 7711-7.( 2009).

48. Saha, M.S., Li, R., Cai, M., Sun, X., High electrocatalytic activity of platinum nanoparticles on $\mathrm{SnO}_{2}$ nanowire-based electrodes. Electrochem Solid State Lett. 10, B130. (2007).

49. Maheswari S, Sridhar P, Pitchumani S. Pd-

Egypt. J. Chem. 60, No.3 (2017) 
$\mathrm{TiO}_{2} / \mathrm{C}$ as a methanol tolerant catalyst for oxygen reduction reaction in alkaline medium. Electrochem Commun. 26, 97-100. (2013)

50. Hyde, T., Final analysis: Crystallite size analysis of supported platinum catalysts by xrd. Platin Met Rev. 52, 129-30. (2008).

51. Zhang, L., Lee, K.C., Zhang, J.J., Effect of synthetic reducing agents on morphology and ORR activity of carbon-supported nano-PdCo alloy electrocatalysts, Electrochimica Acta. 52,7964-71. (2007).

52. Altamirano-Gutiérrez, A., Fernández, A.M., Rodríguez Varela, F.J., Preparation and characterization of $\mathrm{Pt}-\mathrm{CeO}_{2}$ and Pt-Pd electrocatalysts for the oxygen reduction reaction in the absence and presence of methanol in alkaline medium. Int J. Hydrogen Energy. 38,12657-66. (2013).

53. Zhu, H., Li, X., Wang, F., Synthesis and characterization of $\mathrm{Cu} @ \mathrm{Pt} / \mathrm{C}$ core-shell structured catalysts for proton exchange membrane fuel cell. Int J. Hydrogen Energy. 36, 9151-4 (2011).

54. Yu, S., Lou, Q., Han, K., Wang, Z., Zhu, H., Synthesis and electrocatalytic performance of MWCNT-supported Ag@Pt core-shell nanoparticles for ORR. Int J. Hydrogen Energy. 37, 13365-70.(2012).

55. Ruiz-Camacho, B., Martínez-Álvarez, O., Rodríguez-Santoyo, H.H., Granados-Alejo, V., $\mathrm{Pt} / \mathrm{C}$ and $\mathrm{Pt} / \mathrm{TiO}_{2}-\mathrm{C}$ electrocatalysts prepared by chemical vapor deposition with high tolerance to alcohols in oxygen reduction reaction. $J$ Electroanal Chem. 725, 19-24. (2014).

56. Oishi, K., Savadogo, O., Correlation between the physico-chemical properties and the oxygen reduction reaction electro catalytic activity in acid medium of Pd-Co alloys synthesized by ultrasonic spray method. Electrochimica Acta. 98, 225-38. (2013).

57. Tiido, K., Alexeyeva, N., Couillard, M., Bock, C., MacDougall, B.R., Tammeveski, K., Graphene$\mathrm{TiO}_{2}$ composite supported $\mathrm{Pt}$ electrocatalyst for oxygen reduction reaction. Electrochim Acta. 107, 509-17. (2013).

58. Elezovic, N.R., Babic, B.M., Radmilovic, V.R., Vracar, L.M., Krstajic, N. V., Synthesis and characterization of MoOx-Pt/C and TiOx-Pt/C nano-catalysts for oxygen reduction. Electrochim Acta. 54, 2404-9. (2009).

59. Xu, Z., Qi, Z., Kaufman, A., Effect of oxygen storage materials on the performance of protonexchange membrane fuel cells. J. Power Sources. 115, 40-3.(2003).

Egypt. J. Chem. 60, No.3 (2017)
60. Fugane, K., Mori, T., Ou, D.R., Suzuki, A. Yoshikawa, H., Masuda, T., et al. Activity of oxygen reduction reaction on small amount of amorphous $\mathrm{CeO}$ x promoted $\mathrm{Pt}$ cathode for fuel cell application. Electrochim Acta. 56, 3874-83. (2011).

61. Asteazaran, M., Bengio, S., Triaca, W.E., Castro, L. AM., Methanol tolerant electrocatalysts for the oxygen reduction reaction. J. Appl Electrochem.44, 1271-78. (2014).

62. Chung, H.T., Won, J.H., Zelenay, P., Active and stable carbon nanotube /nanoparticle composite electrocatalyst for oxygen reduction. Nature Communications. 4, Article number: 1922. (2013).

63. Moss, R.L., Preparation and Characterization of Supported Metal Catalysts, in: Anderson RB, Dawson PT (Eds.), Experimental Methods in Catalytic Research, Vol. 2, Ch. 2, Academic Press, New York, p. 43. (1976).

64. Yang, J.H., Henao, J.D., Costello, C., Kung, M.C., Kung, H.H., Miller, J.T., Kropf, A.J., Kim, J.G., Regalbuto, J.R., Bore, M.T., Pham, H.N., Datye, A.K. , Laeger, J.D., Kharas, K., Understanding preparation variables in the synthesis of $\mathrm{Au} / \mathrm{Al}_{2} \mathrm{O}_{3}$ using EXAFS and electronmicroscopy. Appl.Catal. A291.73-84. (2005).

65. Wu, S.H., Zheng, X.C., Wang, S.R., Han, D.Z., Huang, W.P., Zhang, S.M., $\mathrm{TiO}_{2}$ supported nano$\mathrm{Au}$ catalysts prepared via solvated metal atom impregnation for low temperature $\mathrm{CO}$ oxidation. Catal. Letters. 97, 17-23. (2004).

66. Liu, Y., Male, P., Bouvrette, P., Luong, J.H.T., Control of the size and distribution of gold nanoparticles by unmodified cyclodextrins. Chem. Mater. 15, 4172-80. (2003).

67. Fernández, J.L., Walsh, D.A., Bard,A.J., Thermodynamic guidelines for the design of bimetallic catalysts for oxygen electro reduction and rapid screening by scanning electrochemical microscopy. M-Co (M: Pd, Ag, Au) J. Am. Chem. Soc. 127, 357-65. (2005).

68. Fernández, J.L., Bard, A.J., Scanning electrochemical microscopy. 47. Imaging electrocatalytic activity for oxygen reduction in an acidic medium by the tip generation-substrate collection mode, Anal. Chem. 75, 2967-74. (2003).

69. Lopez, J.R., Zoski, C.G., Bard. A.J., A.J. Bard, M.V. Mirkin (Eds.), Scanning Electrochemical Microscopy, 2nd ed., CH16, Taylor and Francis, N.Y. p. 525-68. (2012).

70. Amemiya, S., Bard, A.J., Fan, F.R.F., Mirkin, M.V., Unwin, P.R., Scanning electrochemical 
microscopy, Annu. Rev. Anal. Chem. 1, 95-131.; 1: (2008)

71. Fan, F.R.F., Fernandez, J., Liu, B., Mauzeroll, J., Scanning Electrochemical Microscopy, in: C.G.Zoski (Ed.), Handbook of Electrochemistry,Ch.12, Elsevier, Amsterdam. 471-540. (2007).

72. Vellacheri, R., Unni, S.M., Nahire, S., Kharul, U.K., Kurungot, S., Pt-MoOx-carbon nanotube redox couple based electrocatalyst as a potential partner with polybenzimidazole membrane for high temperature polymer electrolyte membrane fuel cell applications. Electrochim Acta. 55, 287887(2010).

73. Kang, H.L., Kyungjung, K., Victor, R., Duck, Y.Y., Hyuk, C., Doyoung, S., Synthesis and characterization of nanostructured $\mathrm{PtCo}-\mathrm{CeO}_{x} / \mathrm{C}$ for oxygen reduction reaction. J. Power Sources. 185, 871-85. (2008).

74. Senthil Kumar, S.M., Soler Herrero, J., Irusta, S., Scott, K., The effect of pretreatment of Vulcan XC$72 \mathrm{R}$ carbon on morphology and electrochemical oxygen reduction kinetics of supported Pd nanoparticle in acidic electrolyte. J Electroanal Chem. 647, 211-21. (2010).

75. El-Deab, M.S., Ohsaka, T., Hydrodynamic voltammetric studies of the oxygen reduction at gold nanoparticles-electrodeposited gold electrodes. Electrochim Acta. 47, 4255-61. (2002).

76. Thanasilp, S., Hunsom, M., Effect of Pt: Pd atomic ratio in $\mathrm{Pt}-\mathrm{Pd} / \mathrm{C}$ electrocatalyst-coated membrane on the electrocatalytic activity of ORR in PEM fuel cells. Renew Energy.36, 1795-801. (2011). 
تحضير و توصيف تراكيب نانومترية من البلاتين و أكاسيد العناصر الانتقالية لتفاعل اختزال الأكسجين في الأوساط الحامضية

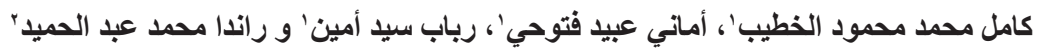

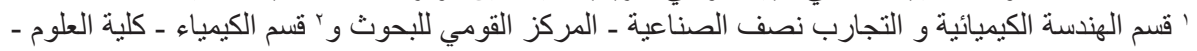
جامعة القاهرة- مصر.

\begin{abstract}
تم تحضير العو امل الحفازة المتكونة من البلاتين و أكاسيد بعض العناصر الانتقالية و المدعمة بالكربون لتطوير عامل

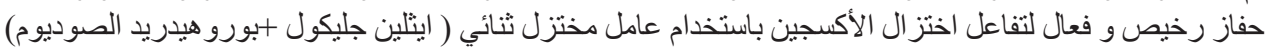

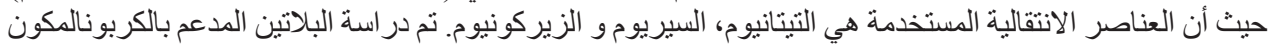

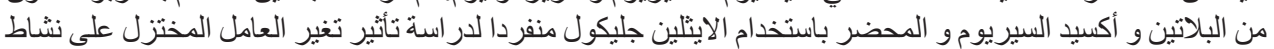

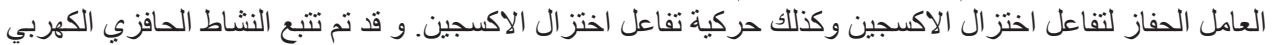

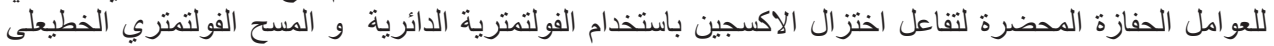

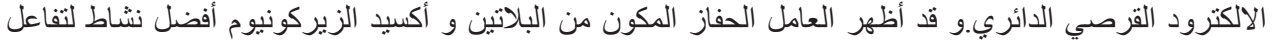

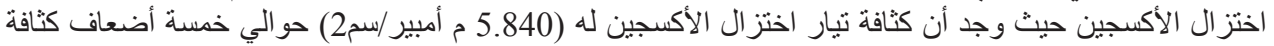

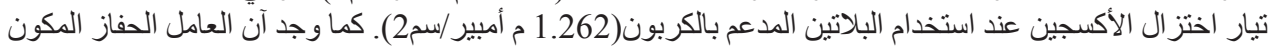

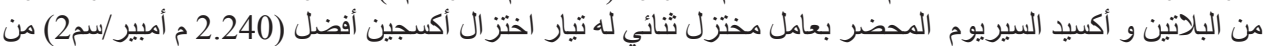

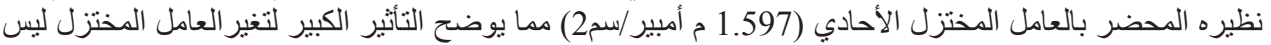

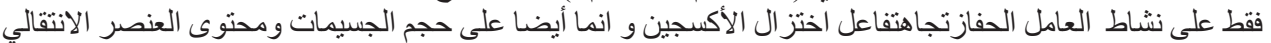

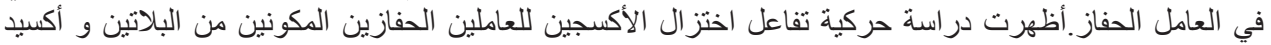

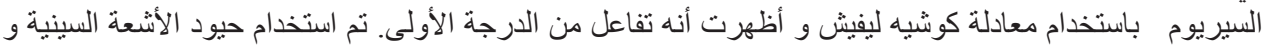

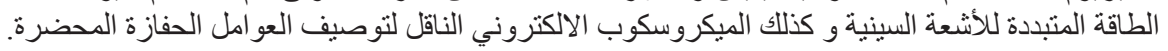

